\title{
31. SEDIMENT FACIES AND PROCESSES ON THE DISTAL BENGAL FAN, LEG $116^{1}$
}

\author{
Dorrik A. V. Stow, ${ }^{2,3}$ Kazuo Amano, ${ }^{4}$ Peter S. Balson, ${ }^{5}$ Garrett W. Brass, ${ }^{6}$ Jeffrey Corrigan, ${ }^{7}$ C. V. Raman, ${ }^{8}$ \\ Jean-Jacques Tiercelin, ${ }^{9}$ Mark Townsend, ${ }^{10}$ and N. P. Wijayananda ${ }^{1 P}$
}

\begin{abstract}
Three closely-spaced sites (Sites 717, 718, and 719) were drilled on the distal Bengal Fan in the central Indian Ocean at a water depth of $4735 \mathrm{~m}$ and to a maximum penetration of $962 \mathrm{mbsf}$. This paper presents a synthesis of results from both shipboard and shore-based studies, with particular emphasis on the lithofacies, their depositional processes, and sediment source.

The sediment record at all three sites can be divided into five distinct lithologic units: Units I, III, and IV are mud-rich with relatively low accumulation rates $(<70 \mathrm{~m} / \mathrm{m} . \mathrm{y}$.), whereas Units II and $\mathrm{V}$ are silt-rich with high rates of sedimentation, in parts in excess of $350 \mathrm{~m} / \mathrm{m} . \mathrm{y}$. The oldest sediments recovered are early Miocene in age, approximately $17 \mathrm{Ma}$.

Seven sediment facies are recognized. Light-gray silt and mud turbidites (Facies 1 and 2) are the most dominant throughout, and were derived from rapid erosion of the Himalayas. Transport was to the Ganges delta/shelf region and then resedimentation occurred downslope, in some cases in very large powerful turbidity currents that traveled over $2500 \mathrm{~km}$ and deposited beds up to $2.5 \mathrm{~m}$ thick. Dark-gray, organic-rich, mud turbidites (Facies 3 ) are interbedded with the other facies, particularly in the mud-rich units. They have a distinctive clay and silt mineral composition that indicates derivation from the continental margin off southeast India and Sri Lanka. Biogenic turbidites (Facies 4), comprising nannofossils, foraminifers, and clay, are much less common. Two types are identified, one from the outer shelf/upper slope off Sri Lanka and the other from a local seamount source. Pelagic clays and calcareous pelagic clays (Facies 5 and 6) are developed as thin caps over some of the mud and biogenic turbidites. They mostly have a low to absent biogenic content, indicating deposition below the carbonate compensation depth for all but the last $2 \mathrm{~m} . \mathrm{y}$., as well as significant early diagenetic dissolution of siliceous microfossils. Continuously bioturbated, structureless muds of part turbidite and part pelagite aspect (Facies 7) are interpreted to have been deposited from a thick suspension cloud above and beyond the distal feather edge of the "true"" turbidity current. These sediments are here termed "hemiturbidites."

The effects of Himalayan uplift, eustatic and local sea-level fluctuations, local tectonics related to intraplate deformation, and fan channel/lobe processes have closely interacted to produce the observed sedimentary record of the past 17 m.y. on the Bengal Fan. Different stages of Himalayan uplift and erosion can be recognized from the composition of distal fan turbidites.
\end{abstract}

\section{INTRODUCTION}

Three sites were drilled on the Bengal Fan during ODP Leg 116. These sites $(717,718$, and 719$)$ were closely spaced on the extreme distal portion of the fan in the central Indian Ocean at a water depth of $4735 \mathrm{~m}$ (Fig. 1). They are located some $50 \mathrm{~km}$ beyond any of the fan channels documented by Emmel and Curray (1984) in an essentially smooth, very low-gradient $(<0.5 \mathrm{~m} / \mathrm{km})$, area that either forms part of a terminal lobe or a smooth lower fan.

\footnotetext{
${ }^{1}$ Cochran, J. R., Stow, D.A.V., et al., 1990. Proc. ODP, Sci. Results, 116 College Station, TX (Ocean Drilling Program).

2 Geology Department, University Park, Nottingham, U.K.

${ }^{3}$ Present address: Geology Department, The University, Southampton, S09 $5 \mathrm{NH}, \mathrm{U} . \mathrm{K}$.

${ }^{4}$ Department of Earth Sciences, Ibaraki University, Bunkyo 2-1-1, Mito 310, Japan.

's British Geological Survey, Keyworth, Nottingham, N912 599 U.K.

${ }^{6}$ Marine Geology and Geophysics, RSAMS, University of Miami, Miami, Florida 33249-1098, U.S.A.

7 Department of Geological Sciences, University of Texas, Austin, Texas 78713-7909, U.S.A. India.

8 Department of Geology, Andhra University, Visakhapatnam 530003,

${ }^{9}$ GIS Océanologie et Géodynamique, Université de Brétagne Occidentale, 29287 Brest Cedex, France.

${ }_{10}$ Geology Department, University Park, Nottingham, U.K.

${ }^{11}$ Oceanography Unit, NARA, Crow Island, Mattakjuliya Colombo 15, Sri Lanka.
}

In the immediate vicinity of the sites drilled there are local irregularities in relief that are the surface expression of underlying deformed ocean crust and overlying sedimentary section (Weissel et al, 1980; Geller et al., 1983). These positive relief features are up to a few tens of meters above the surrounding seafloor just $3 \mathrm{~km}$ south of Site 718 (Fig. 2), and may protrude locally up to $800 \mathrm{~m}$.

The Bengal Fan is one of the world's major elongate submarine fans (Curray and Moore, 1971; Curray et al., 1982; Emmel and Curray, 1984) covering $3 \times 10^{6} \mathrm{~km}^{2}$. It is $2800-3000 \mathrm{~km}$ long, $830-1430 \mathrm{~km}$ wide, and over $10 \mathrm{~km}$ thick beneath the northern Bay of Bengal. Fewer than 100 piston cores have been recovered from the surface sediments, and only one spot-cored DSDP site (Leg 22, Site 218) has previously been drilled into the fan (Von der Borsch, Sclater, et al., 1974).

The size and location of the Bengal Fan is clearly related to collision of the Indian and Eurasian plates and consequent uplift of the Himalayan Mountains. Denudation of the Himalayas has supplied enormous volumes of sediment to the fan via the Ganges-Brahmaputra river systems and delta. Sediments are fed efficiently across the shelf in the northern Bay of Bengal via a delta front trough, the Swatch-of-No-Ground, which is presently connected to only one active fan channel that weaves its way across the full length of the fan. Many other (presently inactive or abandoned) channels mark the fan surface and extend for various distances along its length. Several canyons and channels also cut across the east Indian and Sri Lankan margins, extending into the western part of the fan (Fig. 1). 

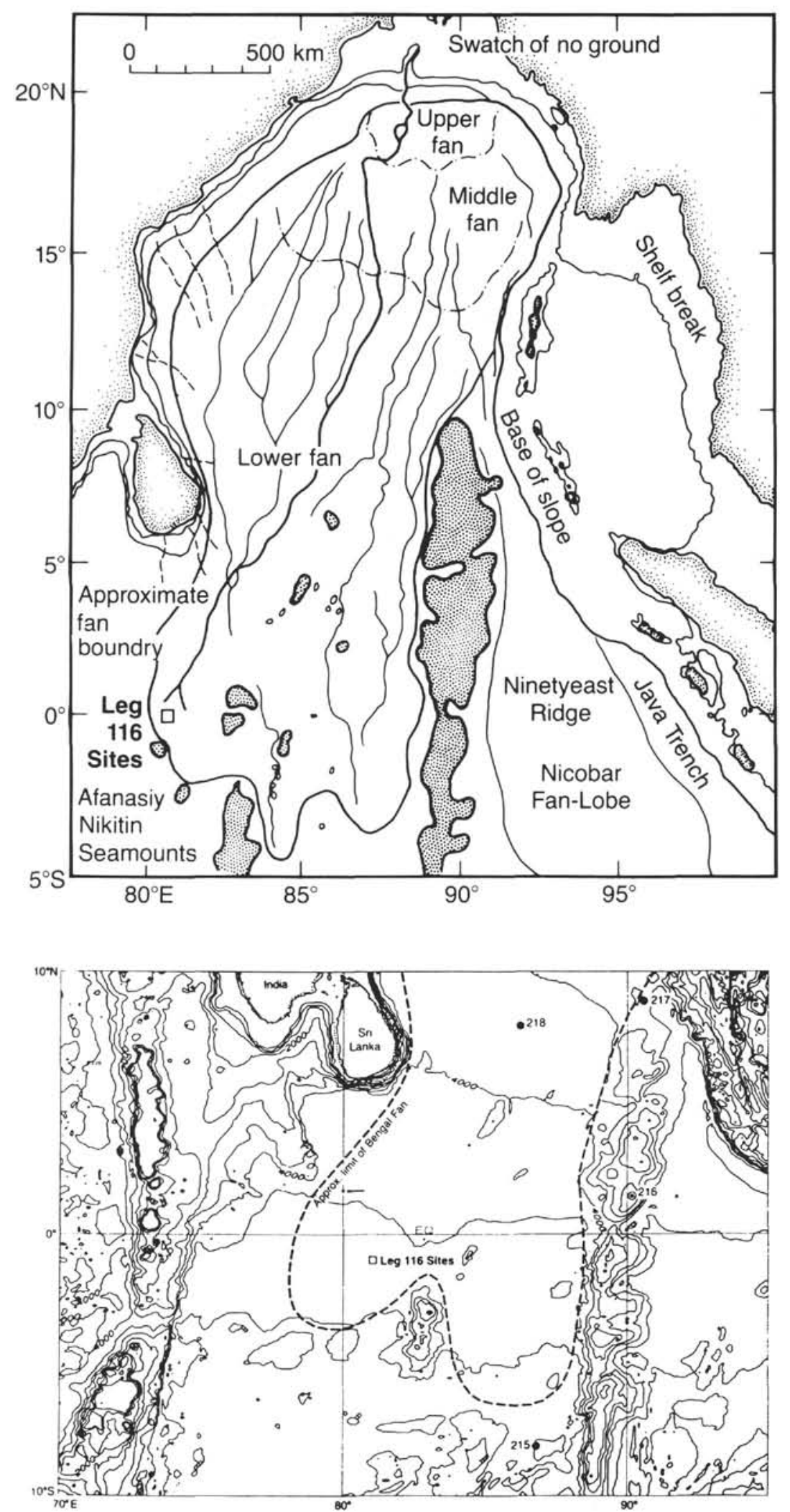

Figure 1. Map of the Bengal Fan (modified after Emmel and Curray, 1984) and location of Leg 116 sites. Solid and dashed lines show channels on the fan and across the Indian-Sri Lankan margins. Seamounts and other topographic highs are indicated by heavy shading. Inset shows detailed bathymetry (contours in meters) in the area of ODP Sites 717, 718, and 719, and DSDP Sites 217, 218, and 219. 


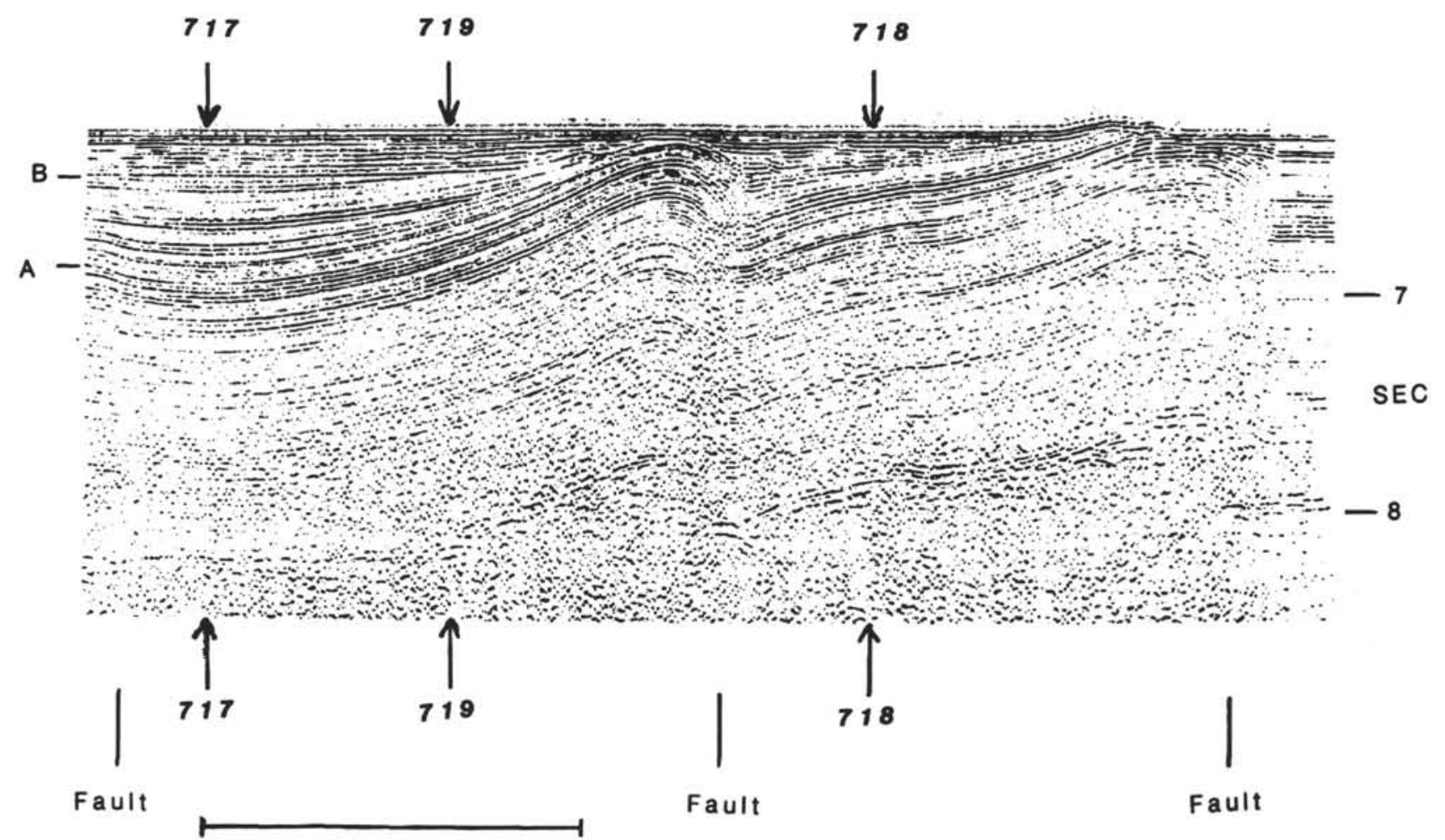

Approx. $5 \mathrm{~km}$

Figure 2. Single-channel seismic reflection profile across the three Leg 116 sites. Prominent unconformities are at A and B. Note slight seafloor relief above up-tilted ends of fault blocks. Y-axis: two-way traveltimes.

This paper summarizes many of the data obtained from both shipboard and shore-based studies, and synthesizes our results with particular emphasis on the lithofacies, their depositional processes, and sediment source. We draw heavily on the various specialist papers also published in this volume, and will not repeat here the methods employed for these different studies. Clay mineralogy and geochemical data of sediments are in back-pocket microfiche.

\section{LITHOSTRATIGRAPHY}

All three sites penetrated a similar sequence of sediment facies and lithologic units, although the thicknesses of these units show significant variations between sites due to their relative positions on two adjacent fault blocks (Fig. 3). At each site, five major lithologic units are recognized, from top to bottom (also see back pocket for Chapter 31):

Unit I-the topmost $2-6 \mathrm{~m}$ of pelagic clayey oozes and mud turbidites.

Unit II-100-150 $\mathrm{m}$ of sandy silt, silt-to-mud, and mud turbidites.

Unit III-10-150 $\mathrm{m}$ of thin to thick mud turbidites interbedded with pelagic clays and biogenic turbidites.

Unit IV-70-230 $\mathrm{m}$ of interbedded silt and mud turbidites with pelagic clays and rare biogenic turbidites.

Unit V-the lower section at all three sites (up to $775 \mathrm{~m}$ thick at Site 718) is dominated by silt and silt-to-mud tur- bidites. The upper part is more silt-rich (Unit Va), whereas reddish brown and green-colored, thin-bedded turbidites and pelagic clays are more common in the lower part (Unit $\mathrm{Vb}$ ).

Coring was continuous at each site although core recovery was very variable, being poor in the silts and generally good in the mud-dominated sections. Average recovery was $60 \%$ at Site $717,30 \%$ at Site 718 , and $40 \%$ at Site 719 . Good suites of wireline logs were obtained through parts of the sections at the two most poorly-recovered sites $(718,719)$, so that lithologic interpretations could be made for the nonrecovered intervals.

Biostratigraphic control is based on closely-spaced samples that for the most part contain a sparse, relatively solutionresistant, mainly nannofossil biota that has been resedimented in turbidity currents. However, a very consistent biostratigraphy was evident at each of the three sites, allowing reasonably accurate dating of the lithologic units and estimation of sediment accumulation rates (Gartner, this volume).

The oldest sediments penetrated (at Site 718) are early Miocene in age, dating from about $17 \mathrm{Ma}$. Much of the ensuing Miocene section of Unit V accumulated at average rates of between 70 and $200 \mathrm{~m} / \mathrm{m}$.y., although the silts were probably deposited more rapidly than the intervening muds. The topmost Miocene and Pliocene sediments of Units IV and III are mainly slowly accumulated $(<70 \mathrm{~m} / \mathrm{m}$.y.) muds and thinner interbedded silty horizons. At the top of Unit III, there is either a hiatus or an extremely condensed section that repre- 


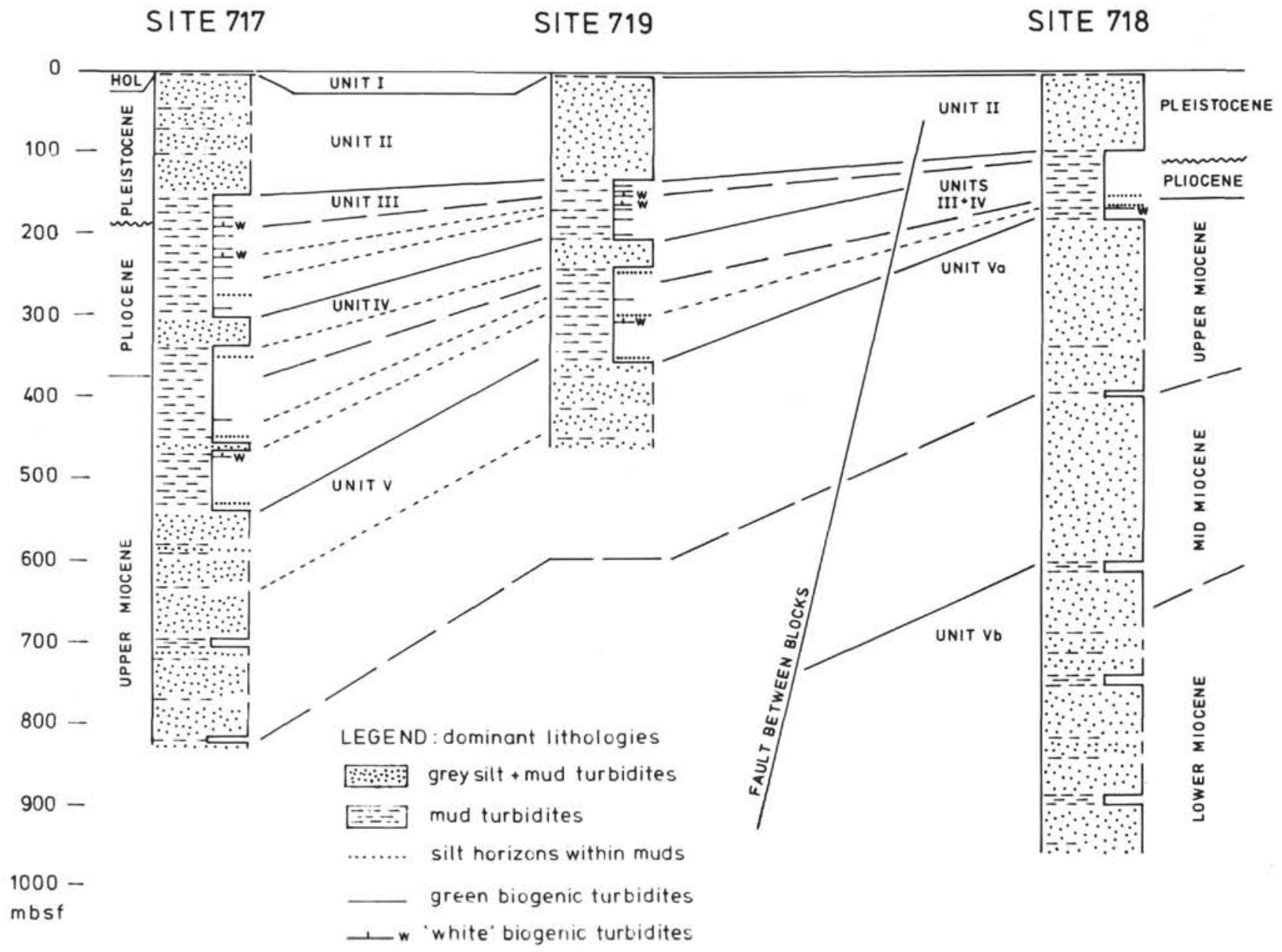

Figure 3. Summary lithostratigraphic sections for Sites 717,718 , and 719 , showing lithologic units and correlations.

sents approximately $1 \mathrm{~m} . \mathrm{y}$. of the early Pleistocene. Late Pleistocene silts of Unit II accumulated most rapidly, at a rate in excess of $350 \mathrm{~m} / \mathrm{m} . \mathrm{y}$. The topmost Holocene/Pleistocene sediments of Unit I accumulated relatively slowly at 15-25 $\mathrm{m} / \mathrm{m} . \mathrm{y}$.

\section{SEDIMENT FACIES}

Seven different facies were recognized during the shipboard description of cores from each of the three sites drilled (Cochran, Stow, et al., 1989). Subsequent laboratory studies have generally confirmed these facies and provided more detailed information on their features, which we outline below. The differentiation of facies on the basis of grain size is shown in Figure 4 (see also Balson and Stow, this volume). Compositional characteristics in relation to source areas are discussed in a subsequent section.

\section{Facies 1: Silt and Silt-mud Turbidites (Fig. 5)}

The entire sequence at all three sites is dominated by turbidites, the most common of which are the light gray colored silt and mud turbidites (Facies 1 and 2), which together make up approximately $68 \%$ of the recovered section. Facies 1, the more silty of these and under-represented due to poor recovery of unconsolidated silts, occurs in thin to very thick beds $(7-160 \mathrm{~cm}$, average $40 \mathrm{~cm})$. Some of the beds are almost wholly of silt with only a few $\mathrm{cm}$ of mud overlying $100-150 \mathrm{~cm}$ silt or sandy silt. Others have only $5 \mathrm{~cm}$ of silt at the base and a thick mud cap; these are gradational to Facies 2 turbidites, which have less than $5 \mathrm{~cm}$ silt. The bases of beds are generally sharp and may be erosive; the tops are also sharply defined by the base of the succeeding turbidite.

Apart from their normal grading, the thicker beds are typically structureless or, more rarely, show a faint horizontal lamination near the base. Thinner beds may show a range of turbiditic structures associated with graded, laminated units as described for Facies 2 below. Bioturbation is mostly rare to absent.

Where thickly developed, the base of these turbidites consists of poorly sorted sandy silt (sand content up to $40 \%$ ) with a mean grain size around 4.5 to 5.0 phi. There is a gradual upward decrease in sand content, a corresponding increase in silt, but low clay content (about 5\%) throughout the turbidite until the uppermost few centimeters, where the clay content increases, the mean size decreases from 5.5 to $7.0 \mathrm{phi}$, and the sorting improves. In the thinner turbidites of Facies 1, the base consists of poorly sorted silt with $15 \%$ sand, the clay content is generally low, and the turbidite tops show a rapid increase in clay with associated fining and improvement in sorting. The maximum size of quartz grains at the base of the thicker beds is coarse sand grade ( 1.0 to 0.5 phi), although wood fragments up to $2 \mathrm{~cm}$ long are locally abundant.

The composition of Facies 1 sediments varies according to both their grain size (relative siltiness) and their depth within the sediment column (or lithologic unit). This last aspect is discussed more fully in a subsequent section on sediment source. The silt-sand fraction is dominated by quartz $(60 \%$ $90 \%$ ), with minor feldspar $(4 \%-36 \%)$, carbonate (mainly do- 


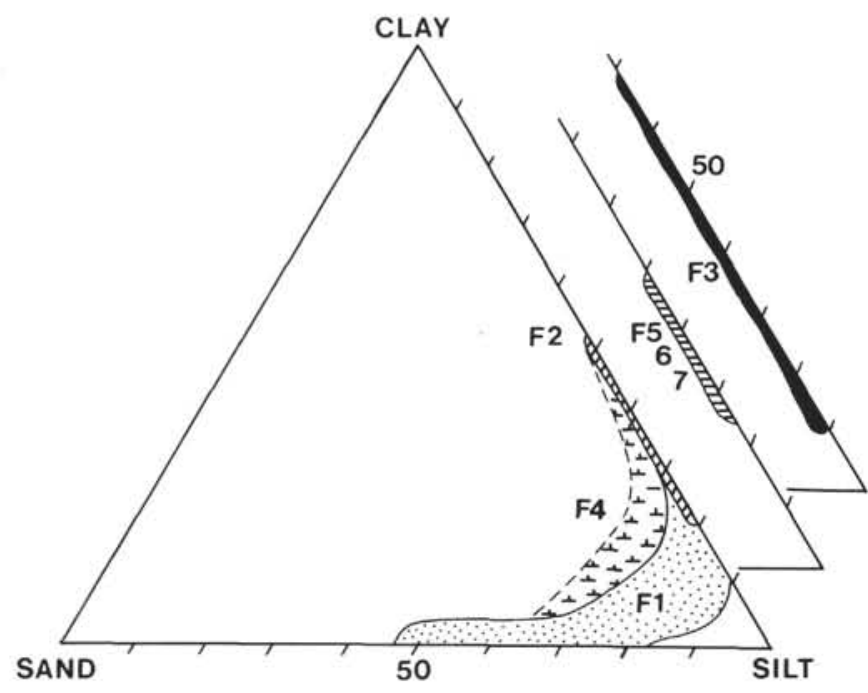

Figure 4. Triangular grain-size plot showing sand-silt-clay percentages of the different sediment facies (areas designated F1, F2, etc).

lomite, $1 \%-16 \%$ ), and more than 25 species of heavy minerals $(1 \%-5 \%)$. The organic carbon content is mostly $<0.5 \%$, only exceeding $1 \%$ where there is a concentration of woody debris. The clay fraction ranges from an illite-chlorite-dominated assemblage in the coarser grained beds, to illite-kaolinite-chlorite in the finer grained beds. Smectite is generally low to absent.

\section{Facies 2: Light-gray Organic-poor Mud Turbidites (Fig. 6)}

The light-gray mud turbidite facies appears to be gradational with Facies 1 (above) and is defined as having less than $5 \mathrm{~cm}$ of silt at the base of a graded mud unit. Within this facies there is also a spectrum of turbidite types. At one end of the spectrum the beds are thick to very thick $(30-250 \mathrm{~cm})$ with, at most, a few thin silt laminae above a sharp flat base. At the other extreme, they are typical thin-bedded turbidites with one or several basal silt laminae overlain by $2-20 \mathrm{~cm}$ of mud.

There is also a range of internal structures, from essentially structureless, thick-bedded muds with slight normal grading, to thin-bedded graded laminated units showing micro-crosslamination, fading ripples, low-amplitude ripples, distinct, indistinct, and wispy silt laminae. The basal silt lamina may show micro-scouring or loading and small-scale flame structures. Bioturbation is rarely intense, but in the medium and thick-bedded units there may be significant burrowing down from the tops of beds so that the muddy tops of the turbidites grade imperceptibly into an overlying pelagic clay.

Facies 2 turbidites consist of moderately sorted clayey silt that fines upward very slightly, at least through the lower part of the bed, and then remains fairly constant in size through the upper part. Typically, the mean grain size is in the range $6.5-7.5$ phi with a clay content between $25 \%$ and $60 \%$. The "cleaner" basal silt laminae, where present, tend to be coarser and more poorly sorted.

The composition of the coarser fraction is very similar to that of the silty turbidites (above); organic carbon content is low and bioclastic material rare. The clay fraction, however, is commonly an illite-kaolinite-smectite assemblage with only minor chlorite. As with the finer grained beds of the silty turbidite facies, there is a trend toward more smectite-kaolinite and correspondingly less illite-chlorite with decreasing grain size.

Facies 3: Dark-gray Organic-rich Mud Turbidites (Fig. 7)

As with Facies 2 above, the dark-gray mud turbidites are thin- to very thick-bedded $(10-180 \mathrm{~cm})$ and mud dominated.
Where silt laminae are present at the base, they rarely extend for more than a few centimeters upward and, more typically, for only a few millimeters. The bases of beds are commonly sharp and flat or micro-scoured, whereas the tops are distinctly gradational into overlying pelagites or "hemiturbidites" (see below). There appears to be a gradation of types from more uniformly dark colored, with only slight upward color grading, to beds with a dark basal turbidite mud, an intermediate mixed-colored, bioturbated mud, and an upper more thoroughly bioturbated, light-colored, probably pelagic mud. They occur at all three sites and are second in importance to the light-gray silt and mud turbidites of Facies 1 and 2 .

In terms of sedimentary structures and textures the dark-gray mud turbidites are again very similar to the light-gray ones described above. The thin silty bases are commonly micro-laminated and cross-laminated; the bed may pass up through a graded laminated unit to graded and then to ungraded mud. Bioturbation from the top downward is typically better developed in these than in the light-gray muds. Where fully developed, a vertical succession of five tiers of biogenic sedimentary structures is recognized. These are, from top down: (1) an uppermost homogeneous layer resulting from surface grazing organisms $1 \mathrm{~cm}$ thick, (2) a layer down to about $5 \mathrm{~cm}$ dominated by Phycosiphon, (3) Planolites down to $10 \mathrm{~cm}$, (4) Chondrites down to $15 \mathrm{~cm}$, and (5) Zoophycos as the deepest burrowing trace down to about $20 \mathrm{~cm}$.

The bulk of these turbidites consists of moderately sorted clayey silts and silty clays with a mean grain size between 7.0 and 8.0 phi, and a clay content between $25 \%$ and $65 \%$. The basal part may be a poorly sorted silt (mean size around 6.0 phi) with $<1 \%$ sand content. Normal grading is ubiquitous but slight, and may be absent in the upper parts of thick beds.

The dark-gray turbidites have a very distinctive composition. The clay assemblage is exclusively smectite-kaolinite with no trace of either illite or chlorite. The quartz-feldspar silt fraction contains an unusual accessory heavy mineral suite including abundant $\mathrm{M}_{\mathrm{g}}$-rich ilmenite, An-rich plagioclase, $\mathrm{Mg}$ rich garnet, and brown hornblende. In addition, the muds typically contain a significant amount $(5 \%-10 \%)$ of calcareous nannofossils and up to $2.5 \%$ organic carbon as fine-grained, dispersed woody debris. Iron sulfides are very common as microscopic framboids, thin mycelia, and larger pyritized burrows, microfossils, and concretions. Partly as a result of the iron monosulfides and ilmenite content, these beds commonly show a high magnetic susceptibility signature that is typically highest in the basal silts and decreases upward through the turbidite (Sager and Hall, this volume).

\section{Facies 4: Biogenic Mud Turbidites (Fig. 8)}

This facies comprises two types of biogenic turbidite: (1) normally graded beds of olive-gray and greenish gray-colored calcareous silty clays that range in thickness from 10 to 190 $\mathrm{cm}$, and (2) thinner bedded (typically $3-15 \mathrm{~cm}$ ), whitish colored silt turbidites, either with a high percentage of benthic foraminifers or of mainly unidentifiable carbonate silts. Both occur as a minor facies within the mud-rich Units III and IV, and the whitish turbidites also appear deeper in the section in Unit $\mathrm{Vb}$ at Site 718.

1. The greenish turbidites are typically sharp based, in some cases showing a distinctly erosive nature, and may have a basal silt layer up to about $8 \mathrm{~cm}$ thick. These silts commonly show internal lamination and cross-lamination, and the lower parts of thick beds may display a faint horizontal lamination. Otherwise the beds appear structureless and are bioturbated to a greater or lesser extent from the top downward. 


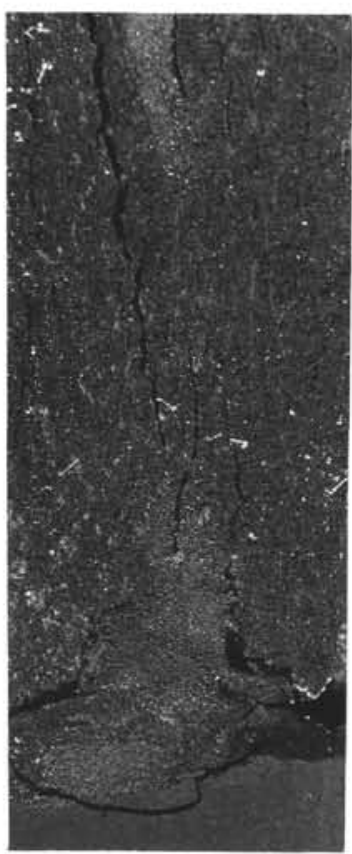

A

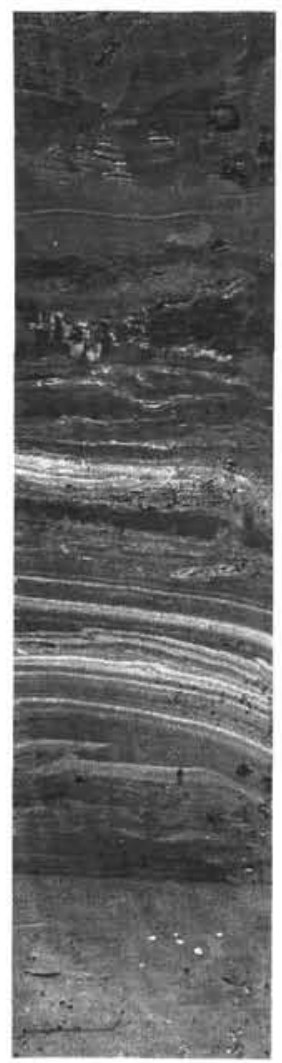

D

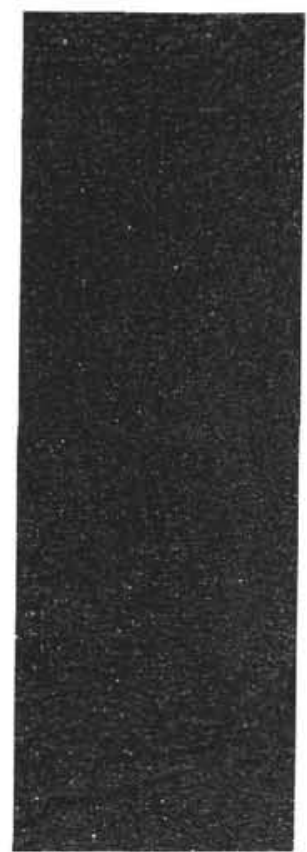

B

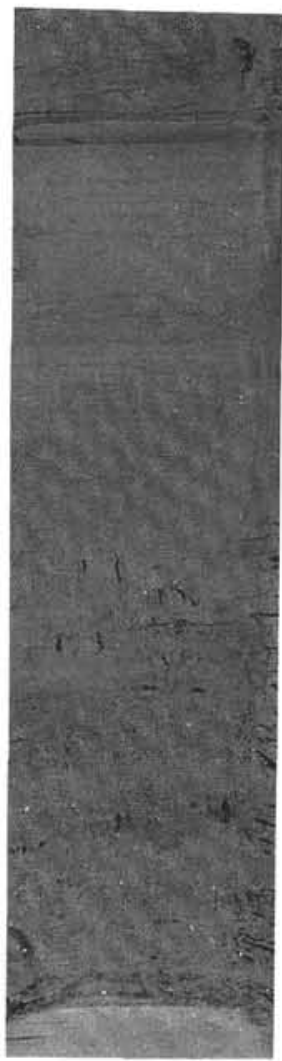

$E$

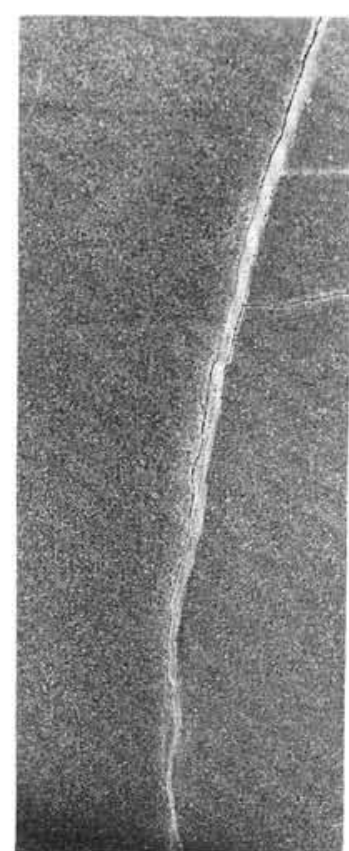

C

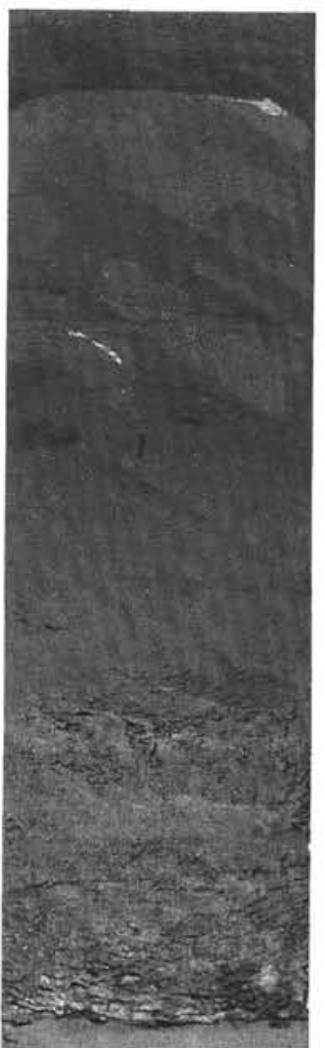

$\mathbf{F}$

Figure 5. Facies 1 photographs: Silt and silt-mud turbidites. A. Section 116-718C-2H-3, details of erosive base of thick, structureless unit. B. Section $116-717 \mathrm{C}-2 \mathrm{H}-4$, mid part of thick, structureless turbidite unit. C. Section 116-717C-87X, CC, part of medium-thick turbidite, structureless to faintly laminated, carbonate-cemented. D. Section 116-718C-46X-1, silt-laminated base of medium-thick turbidite, syn-sedimentary fault and micro-cross-lamination. E. Section 116718C-32X-1, muddy silt base of medium-thick turbidite. F. Section 116-717C-42X-3, muddy silt base of thin turbidite. 


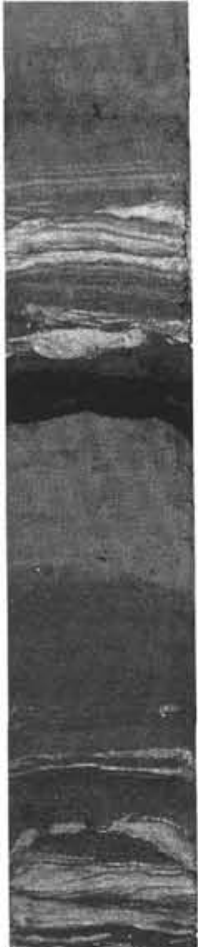

A

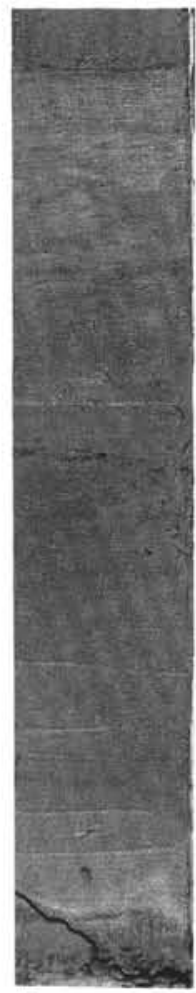

D

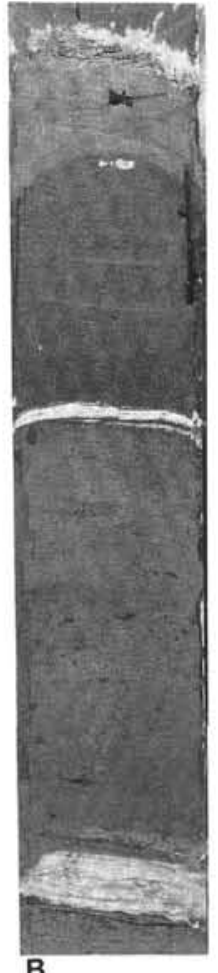

B

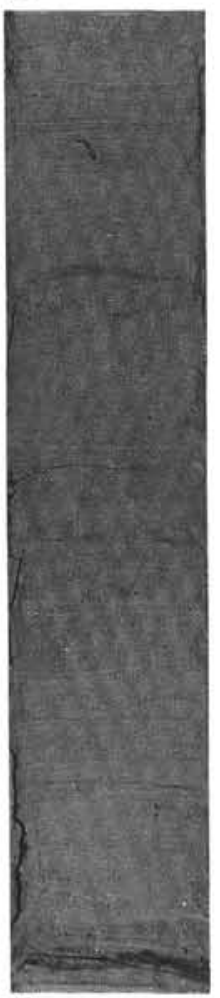

E

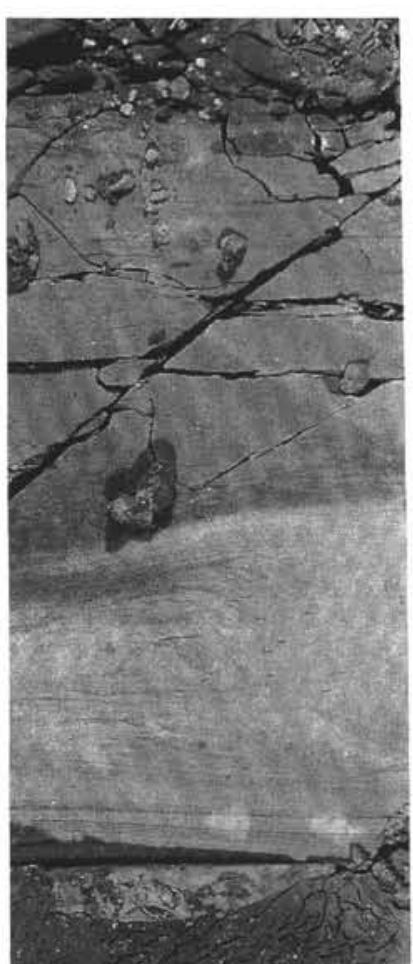

C

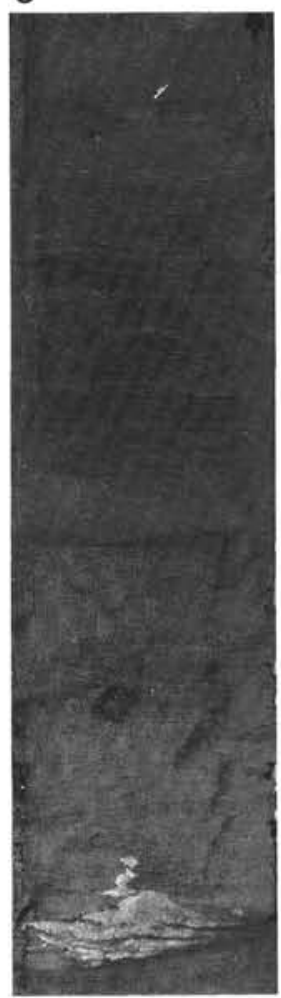

$\mathbf{F}$

Figure 6. Facies 2 photographs: light-gray organic-poor mud turbidites. A. Section 116-718C-14X-5, thin turbidites with silt-laminated bases, scours, and micro-crosslamination. B. Section 116-719A-31X-6, as in A. C. Section 116-718C-94X-6, thin turbidite grading from green silt at base to red mud at top, micro-lamination, cross-lamination, convolution, and scours. D. Section 116-719A-1H-3, medium-thick turbidite with little basalt silt. E. Section 116-717C-27X-6, base of thick turbidite with little silt. F. Section 116-719A-31X-2, thin turbidite with thin silty base. 


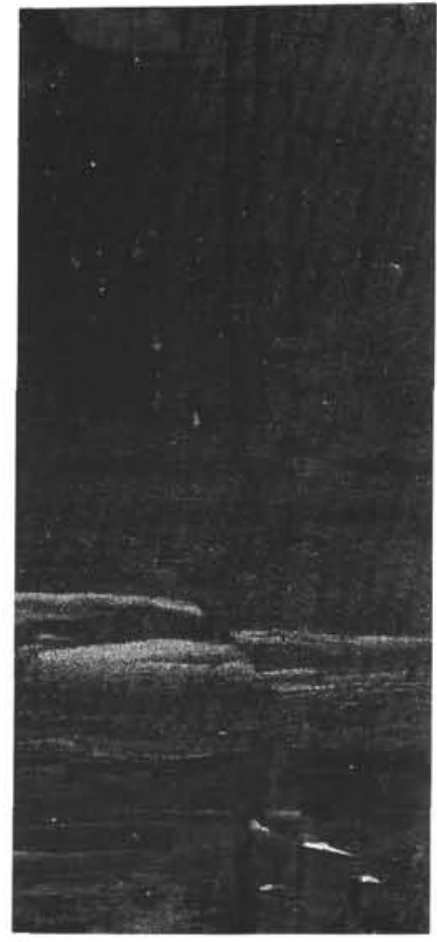

A

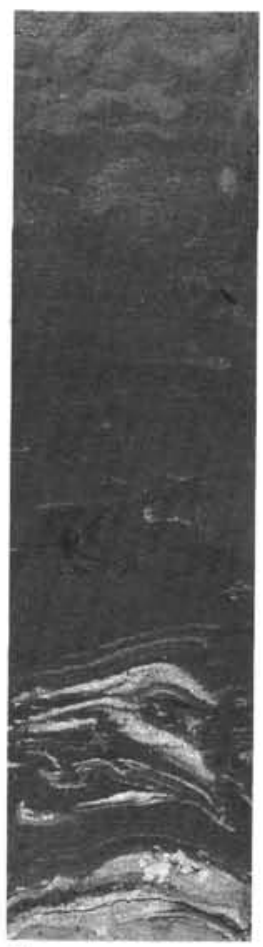

D

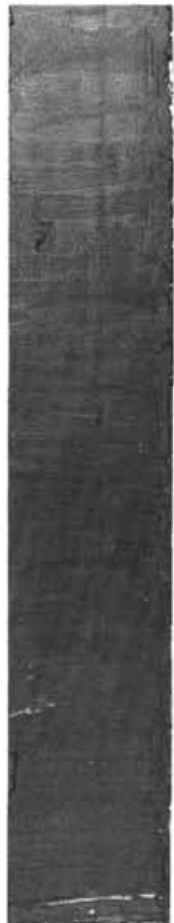

B

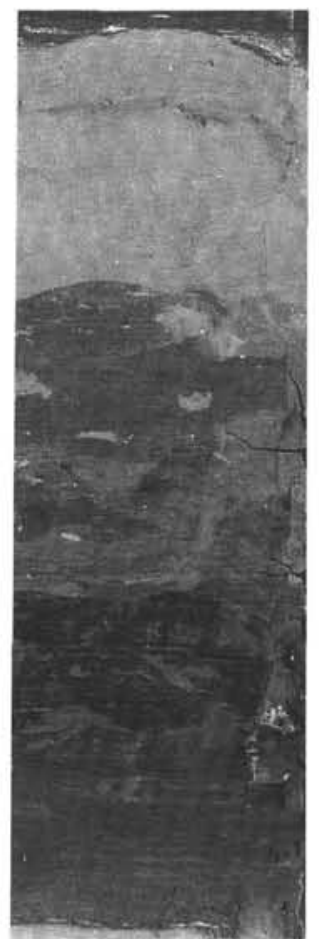

E

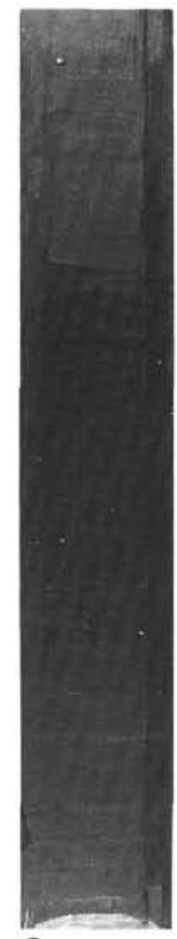

C

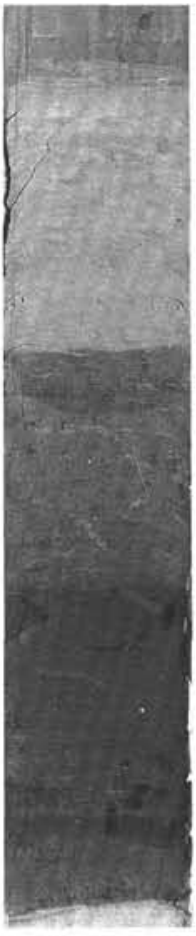

$\mathbf{F}$

Figure 7. Facies 3 photographs: dark-gray, organic-rich mud turbidites. A. Section 116-717C-35X-6, detail of silty base of thick turbidite, syn-sedimentary fault. B. Section 116-717C-27X-4, medium-thick turbidite. C. Section 116-719A-16X-5, medium-thick turbidite. D. Section 116-718C-14X-3, thin turbidites with silty base and convolute lamination. E. Section 116-718C$14 \mathrm{X}-4$, thin turbidite grading up to pale-gray pelagite, thin silt lamina at base. F. Section 116-719A-16X-6, same as E. 


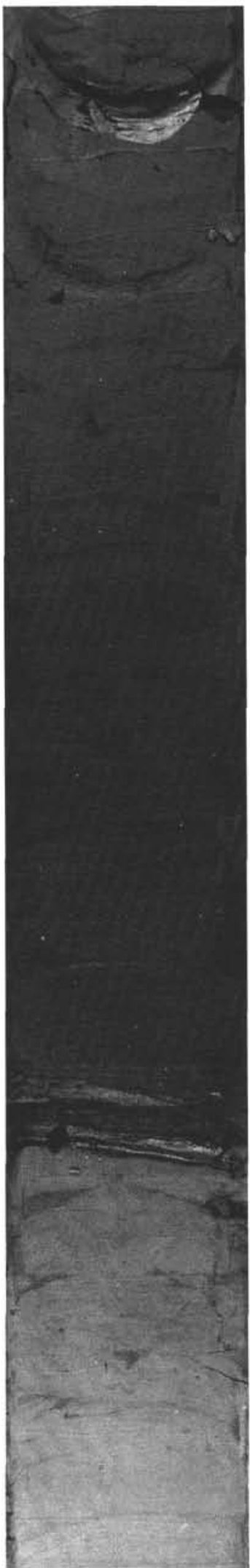

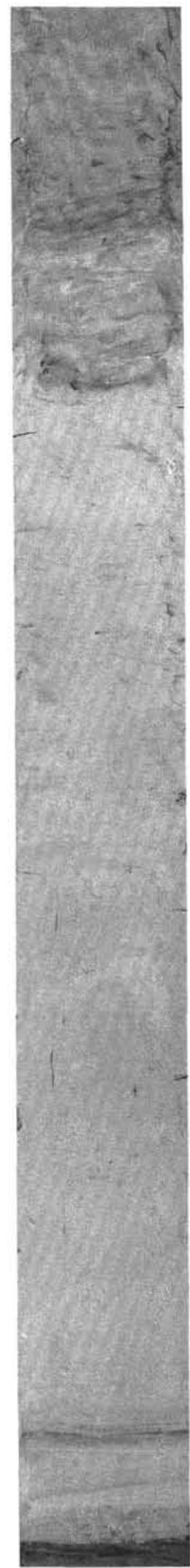

B

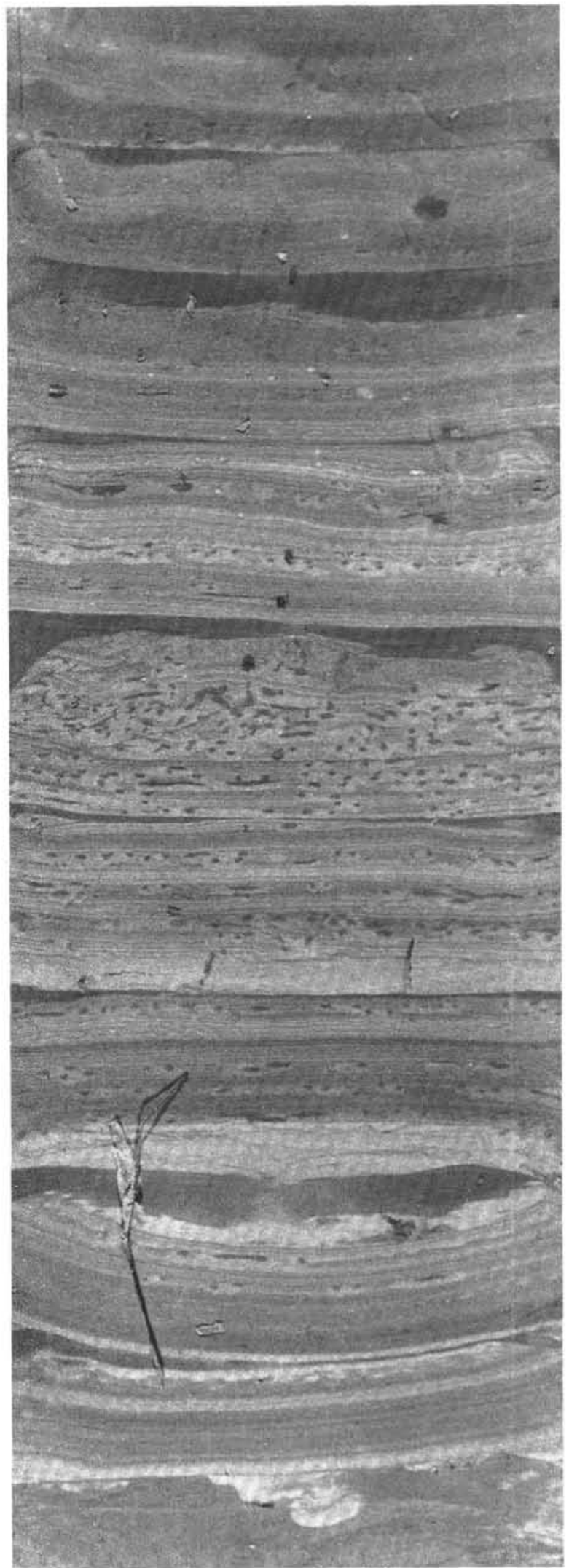

C

Figure 8. Facies 4 photographs: biogenic mud turbidites. A. Section 116-717C-27X-5, lower part of thick green foraminifer-nannofossil turbidite. B. Section 116-717C-28X-5, medium-thick white foraminifer turbidites. C. Section 116-718C-78X-5, repeated thin carbonate (foraminifer) silt-laminated turbidites. 


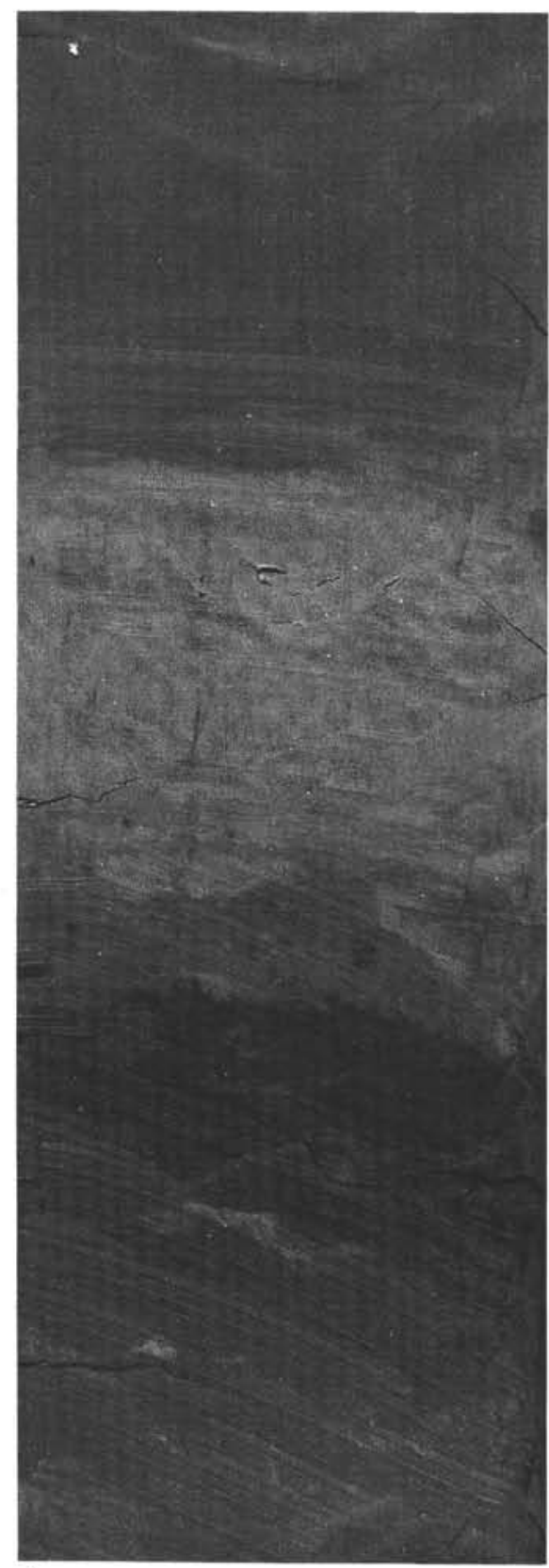

A

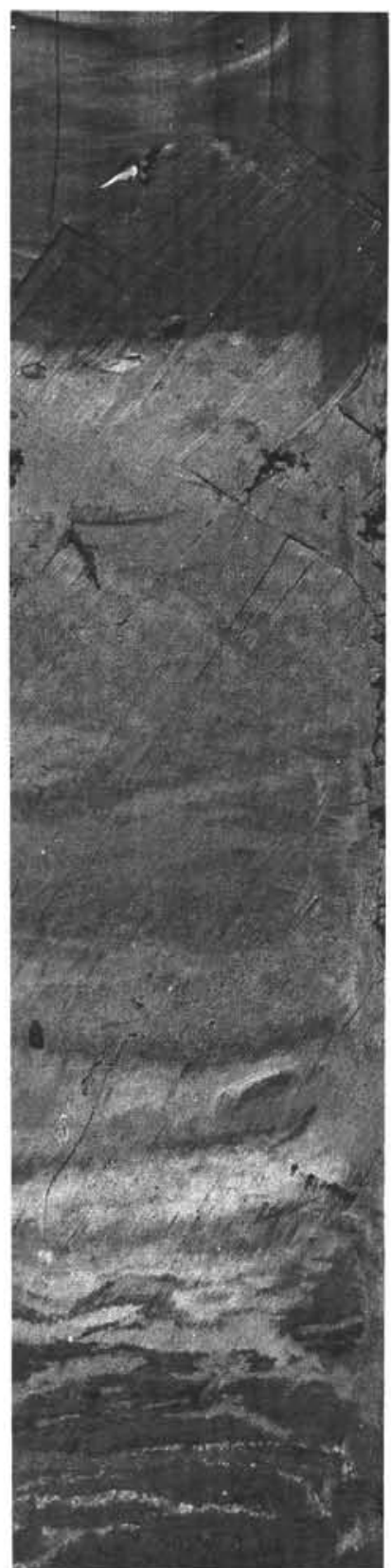

B

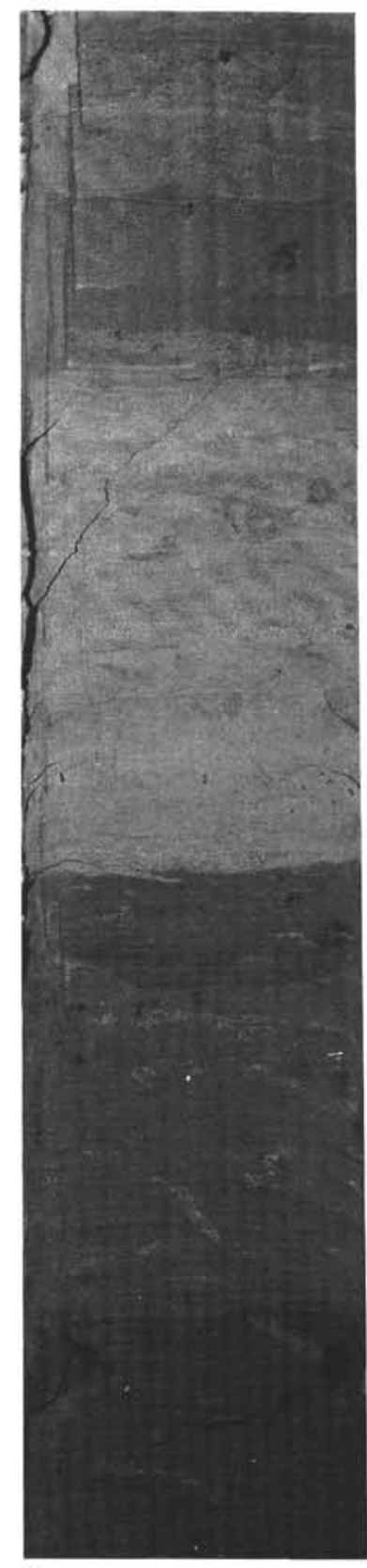

C

Figure 9. Facies 5 photographs: pelagic clays (light-colored unit). A. Section 116-717C-21X-4, thin bioturbated pelagite. B. Section 116-717C-24X-3, thin bioturbated pelagite; dark band is manganiferous chemical front. C. Section 116-719A-16X-6, thin bioturbated pelagite.

These turbidites consist of poorly sorted clayey silt with a basal sandy silt that may contain up to $20 \%$ sand. Sand content gradually decreases upward through the turbidite, but remains present almost throughout. Clay content is $30 \%-40 \%$ through most of the bed, but decreases downward to less than $10 \%$ near the base. The mean grain size at the base is typically 5.0 to 6.0 phi, rapidly fining upward to around 6.5 phi and then more gradually to 7.5 phi near the top. Sorting improves upward through the bed from a poorly sorted basal silt.

In terms of composition, these are bioclastic turbidites with up to $50 \%$ carbonate content. Nannofossils are dominant, foraminifers are abundant in the basal silts together with unidentified calcareous debris. The benthic foraminifer assemblage is typical of outer shelf to upper slope depths. In the few samples analyzed, the clay fraction is composed of smectite- kaolinite-illite, with trace amounts of palygorskite and some gibbsite. Organic carbon contents are low $(0.2 \%$ to $0.8 \%)$.

2. The whitish turbidites have been less well studied in the laboratory. They are sharp-based, normally graded silts and sandy silts, with internal lamination and cross lamination. They are generally more carbonate-rich than the greenish turbidites, with up to $60 \%$ or $70 \%$ carbonate. The benthic foraminifer assemblage indicates bathyal to lower slope depths. The "unidentifiable" carbonate grains appear, in some cases, to be highly corroded remains of foraminifer tests.

\section{Facies 5: Pelagic Clays (Fig. 9)}

The turbidites at all three sites drilled are separated, in some cases, by thin to medium-thick intervals of bioturbated 


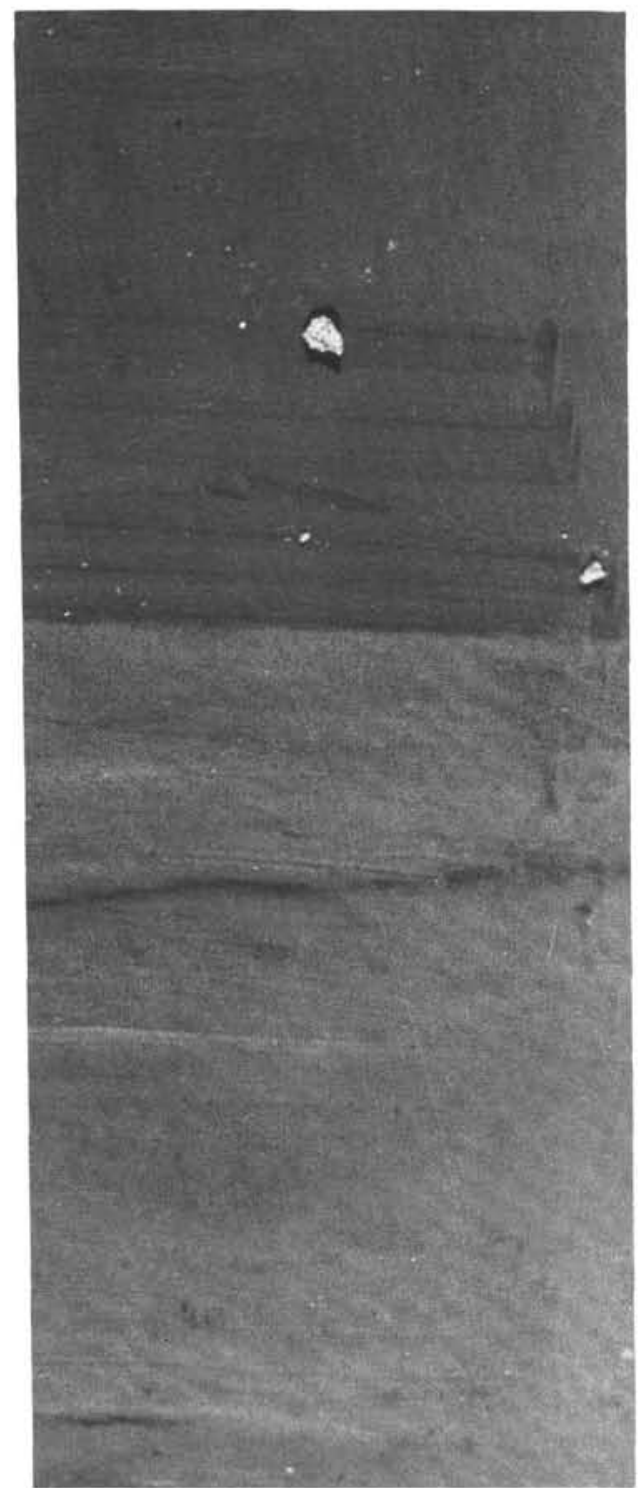

A

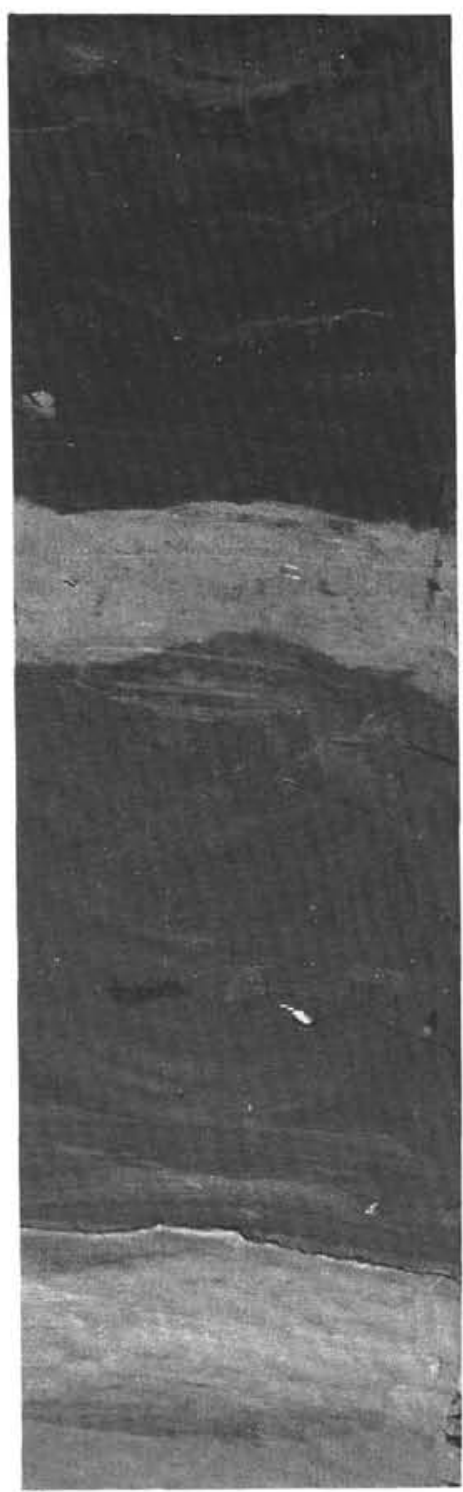

B

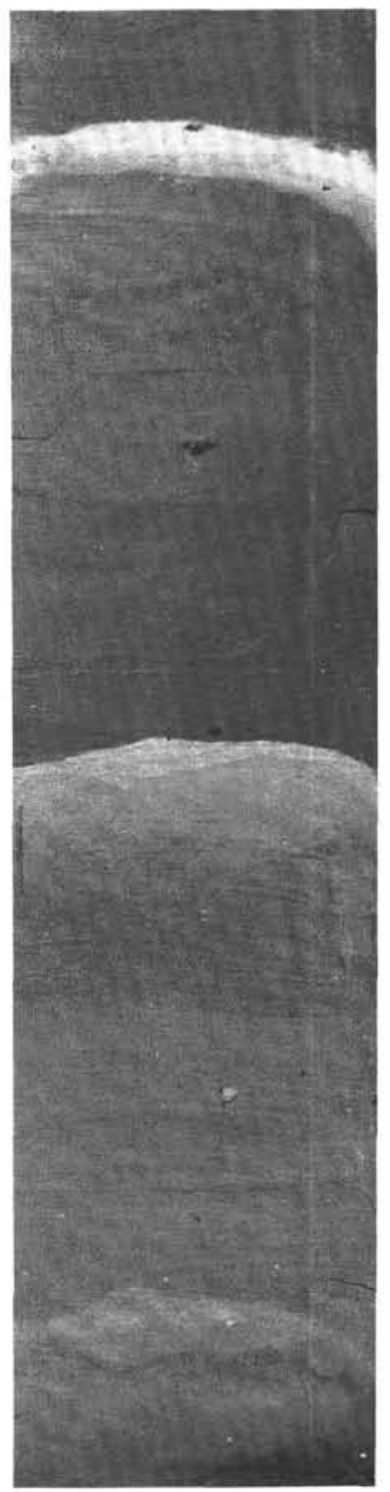

C

Figure 10. Facies 6 photographs: pelagic calcareous clays (thin, light-colored units between darker mud turbidites). A. Section 116-717C-10X-1, very thin bioturbated pelagite with dark manganiferous chemical front about $3 \mathrm{~cm}$ below base of dark turbidite. B. Section $116-717 \mathrm{C}-21 \mathrm{X}-4$, very thin bioturbated pelagites. C. Section $116-717 \mathrm{C}-22 \mathrm{X}-5$, very thin bioturbated pelagites.

clays and silty clays that are interpreted as pelagic in origin, but deposited below the carbonate compensation depth. Light-gray to whitish colored pelagic clays are most common and thicker $(15-25 \mathrm{~cm})$ in the mud-rich Units I, III, and IV, and thin $(<5 \mathrm{~cm})$ to absent in the silt-rich Units II and V. Certain intervals within Unit V contain mottled greenish and reddish colored clays that are also interpreted, in part, as pelagic. These occur near the base of Sites 717 and 718 .

The pelagic clays are characterized by intense bioturbation that typically extends downward into the underlying turbidite. The normal tiering structure of biogenic traces can be recognized within the thicker intervals, as described for Facies 3 above. No primary sedimentary structures are apparent. A faint brownish purplish color lamination, typically found 5-15 $\mathrm{cm}$ below the tops of beds, is interpreted as a diagenetic chemical front or redox boundary within the sediment column. The bases of beds are completely gradational, so that it is not really possible to clearly distinguish turbidite from pelagite, whereas the tops of beds are sharply defined by the base of the succeeding turbidite.

The grain size of pelagic intervals is typically uniform and very fine grained (mean size $7.5-8.0$ phi) with a relatively high clay content (in excess of $40 \%$ ). In terms of composition, they are very similar to the light gray mud turbidites (Facies 2), with a clay assemblage of smectite-kaolinite-illite, very little biogenic material apart from rare highly corroded nannofossils, and low organic carbon contents.

\section{Facies 6: Pelagic Calcareous Clays (Fig. 10)}

In the upper parts of the section recovered at all three sites, the pelagic intervals between turbidites have an increasing amount of biogenic material upward through the section. This biogenic component is dominated by nannofossils, with fewer foraminifers and siliceous microfossils, the latter only being common in the topmost core at Site 717. Typically, these pelagic intervals are thin $(0.5-10.0 \mathrm{~cm})$, whitish colored, 


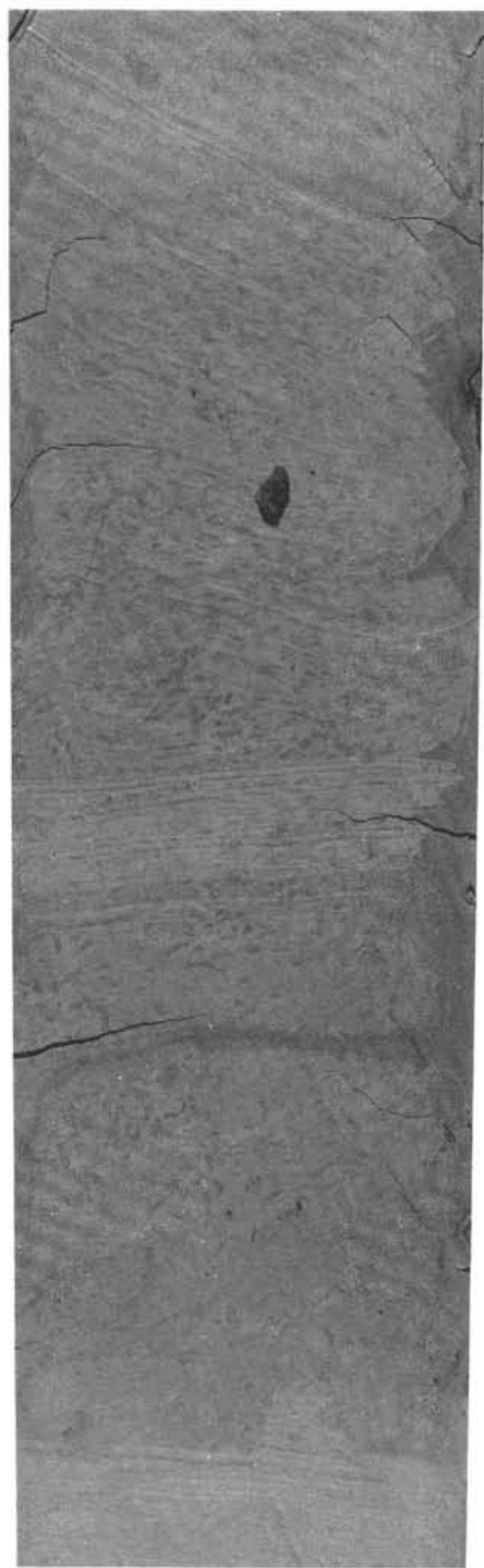

A

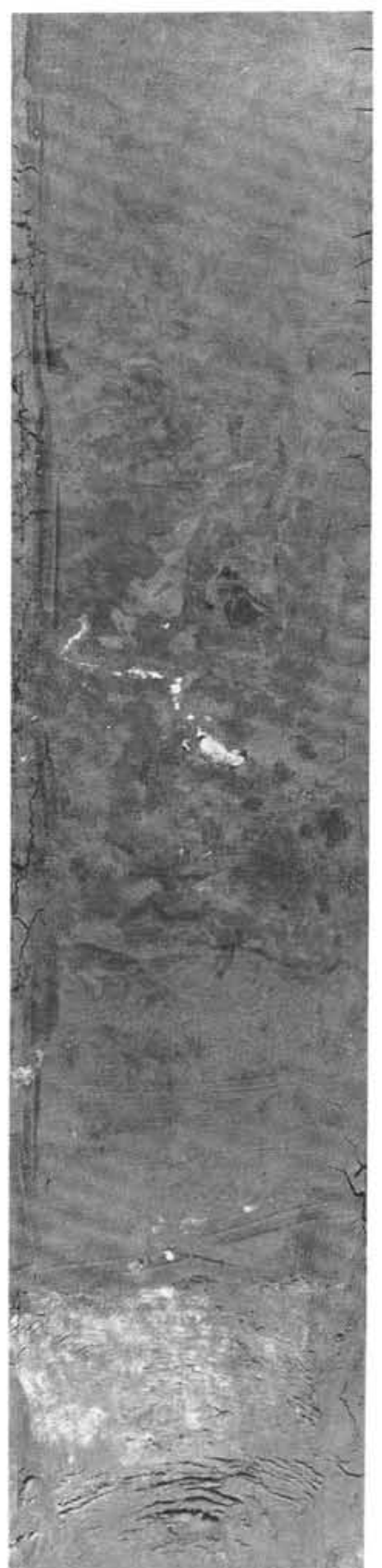

B

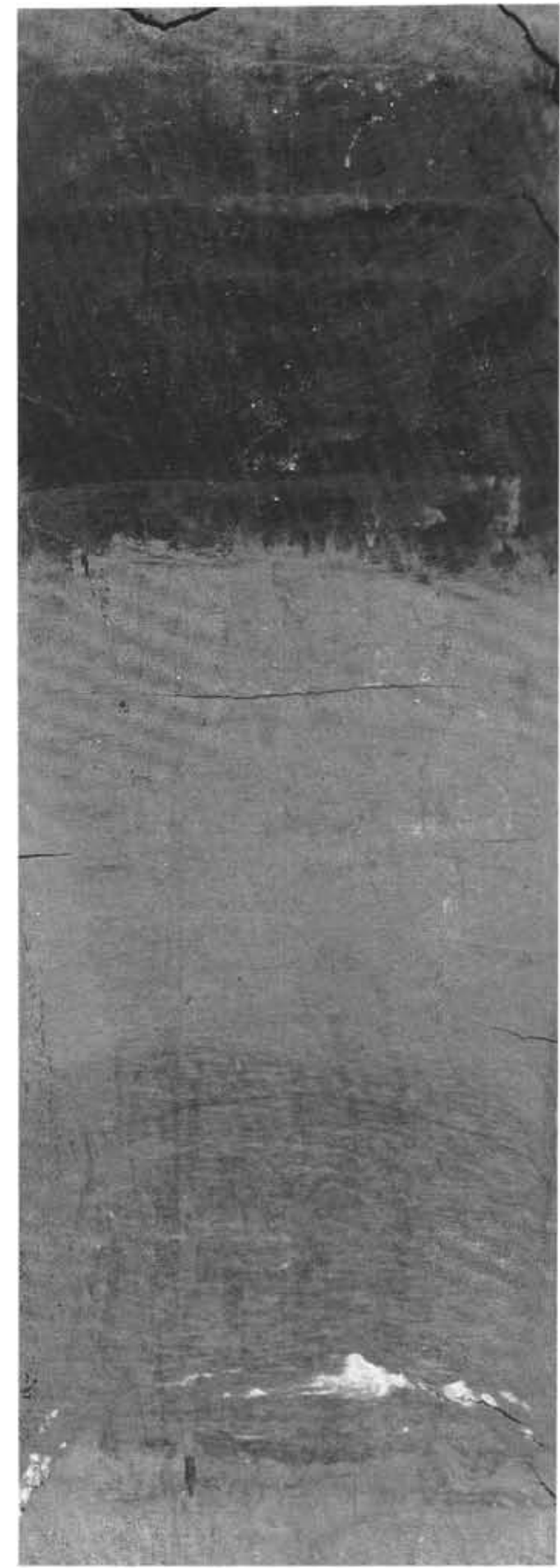

C

Figure 11. Facies 7 photographs: structureless bioturbated muds (termed "hemiturbidites" by Stow and Wetzel, this volume). A. Section 116-717C-26X-6, part of thick bioturbated unit. B. Section 116-718C-11X-3, part of thick bioturbated unit C. Section 116-718C-20X-1, detail of contact at base of hemiturbidite. Note that bioturbation continues throughout.

thoroughly bioturbated, and otherwise very similar to the non-calcareous pelagites described above (Facies 5). They were deposited under conditions of a deepening carbonate compensation depth that allowed preservation of at least part of the biogenic fraction.

\section{Facies 7: Bioturbated Muds_- "Hemiturbidites"' (Fig. 11)}

One relatively common and distinctive sediment type found at each of the three sites drilled showed characteristics intermediate between the mud turbidites and pelagites outlined above. These sediments are described in detail in a separate paper (Stow and Wetzel, this volume), in which they have been called "hemiturbidites." They are most common in the mud-rich Units III and IV at Sites 718 and 719.

Typically, the hemiturbidites are thick $(50-100 \mathrm{~cm})$ turbidite-like beds similar in some ways to either the light gray or the dark gray mud turbidites of Facies 2 and 3. They may have a thin (about $5 \mathrm{~cm}$ ) basal zone of structureless turbidite mud overlain by a thick bioturbated interval. In other cases the basal turbidite is either thicker or completely absent. Where the bioturbated mud interval is only relatively thin, it is difficult to distinguish from the bioturbated top of a turbidite or from a normal pelagite. Indeed, there appears to be a complete gradation between the three facies types. 

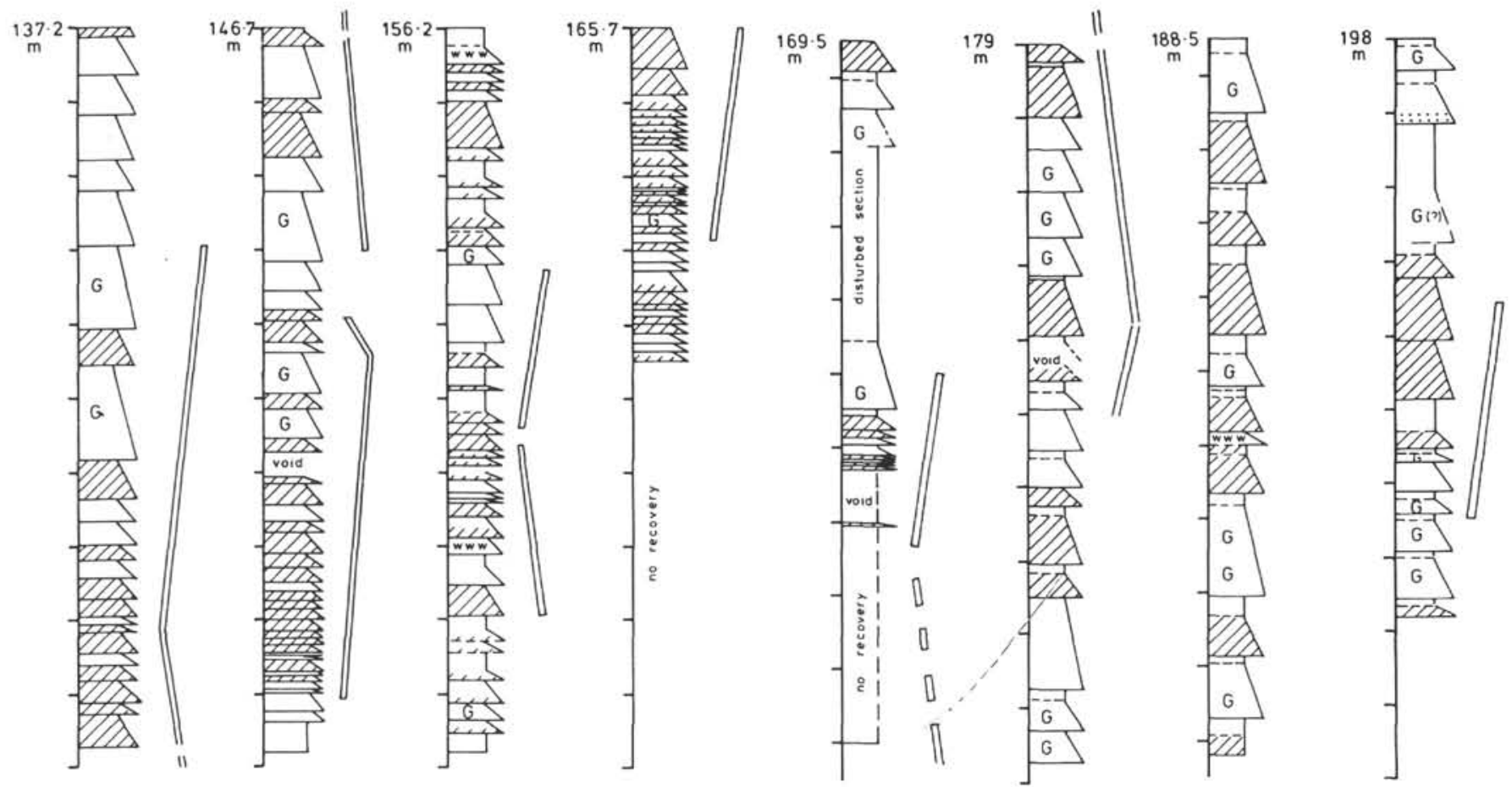

Figure 12. Schematic core logs from Leg 116 sites showing typical small-scale sequences of turbidite thickness. Thinning upward and thickening upward patterns are indicated by double lines to the right of the core sections. Facies 1 and 2 (blank ornament, graded beds), Facies 3 (oblique hachure, graded beds), Facies 4 (graded beds; $\mathrm{G}=$ greenish, $\mathrm{W}=$ whitish), Facies 5,6 , and 7 (blank ornament at tops of graded beds).

The nature of the bioturbation is distinctive, in that the normal tiering zonation is disrupted by the development of the shallower tiers (homogeneous surface tier and shallow Phycosiphon tier) at deeper levels within the beds as well as through much of the bed thickness. Bioturbation thus appears to have been continuous with sedimentation rather than being a top-downward, post-depositional process.

Only the very finest sediment is present in the hemiturbidites (mean size 7.5-8.5 phi), but in some cases an extremely subtle normal grading can be detected both from grain-size measurements and from variation in geotechnical properties such as bulk density. Where the beds pass from a darker colored basal part into a lighter colored upper part, there is a compositional grading apparent from the smectitekaolinite clay mineral assemblage typical of Facies 3 to the smectite-illite-kaolinite assemblage that characterizes the pelagic clays. Slight enrichment in nannofossils and in organic carbon is confined to the darker gray intervals.

\section{FACIES DISTRIBUTION}

\section{Vertical Facies Distribution: Cycles and Sequences}

The first-order distribution of facies observed at all three sites drilled on the distal fan is their partition into mud-rich and silt-rich intervals, here designated as lithologic units (Fig. 3 ). This occurs at a scale of about $100-500 \mathrm{~m}$, with Units II, part of IV, and V being dominated by silt turbidites of Facies 1 together with minor mud turbidites and Units I, III, and most of IV being dominated by mud turbidites, pelagites, and hemiturbidites of Facies 2, 3, 4, 5, and 7.

A second-order distribution of facies occurs within these lithologic units on a scale of a few tens of meters. Within the silty units and particularly evident in Unit V at Site 718, there is an alternation between 5- and 20-m-thick intervals of thin-bedded turbidites and pelagic clays, and somewhat thicker sections (up to $60 \mathrm{~m}$ ) of medium to thick-bedded silt and silt-mud turbidites without identifiable silt layers. Within the mud-rich units, particularly unit IV, the reverse is apparent, in that thinner horizons of silt turbidites alternate with thicker sections of muds. In both cases, these mesosequences of variation in turbidite coarseness and thickness are of an oscillation of symmetrical type (e.g., Ricci Lucchi 1975, Stow, 1985).

A third-order distribution of facies or small-scale (2-10 m) cyclicity in turbidite bed thickness is observed in both wireline logs and cores at each of the three sites. These are varying degrees of organization into patterns of bed thickness variation, from moderately well ordered to completely random (Fig. 12). The well-ordered microcycles are typically 2-10 m in thickness and involve between 10 and 30 turbidite beds. Thinning upward, thickening upward and symmetrical cycles are observed that show, with some internal variability, progressive increase and decrease in bed thickness, from about 10 $\mathrm{cm}$ to $120 \mathrm{~cm}$. However, the majority of the section shows no very well defined microcycles and is characterized by either showing partial cycles or with what appears to be random thickness variation. In no cases do the beds remain of constant thickness (within $10 \%$ variation) for more than a few consecutive beds.

\section{Horizontal Distribution: Turbidite Correlation}

The five lithologic units identified first at Site 717 can be correlated across the $8 \mathrm{~km}$ between the three sites drilled (Fig. $3)$, although the thicknesses of each vary markedly and the distinction between Units III and IV is not clear at Site 718. Individual turbidites within the silt-rich Units II and V cannot be correlated between sites. This is at least partly because of the very poor recovery of silty sections and because of the uniform nature of the turbidites themselves. 
More accurate site-to-site correlation, however, is possible within the mud-rich Units III and IV using distinctive white bioclastic turbidites as marker beds. In this way it has been possible to correlate a bed at Site 717 (Core 116-717-24X, 194 mbsf) with a bed at Site 719 (Core 116-719-18X, 156.5 mbsf), and hence to observe the lateral thickness variation of the overlying and underlying turbidite packages over a distance of about $3 \mathrm{~km}$. In general terms, the thin-bedded turbidites at Site 719 correlate with thicker-bedded turbidites at Site 717, over a few meters immediately adjacent to the white marker horizons. However, one cannot be confident about correlation of other non-distinctive beds or extension of the correlation vertically with precision, as too many individual turbidites appear to pinch out completely between the two sites (Fig. 13).

The thinning of some beds and disappearance of others can be explained by the fact that Site 719 was located part way up a tilted fault block that was active during sedimentation (Cochran, Stow et al., 1989). Southward-moving turbidity currents were affected by the slight (? few tens of meters) seafloor relief and either veered off to the side or continued on up the slope, depositing thinner beds, perhaps due to an increase in flow velocity.

Still fewer beds can be correlated with any degree of certainty from Site 719 to Site 718 , which sits part way up the fault block immediately to the south, some $5 \mathrm{~km}$ from Site 719. Very few turbidity currents appear to have traversed the elevated nose of the more northerly of the two adjacent blocks and then deposited material to the south. Only one distinctive white turbidite near the base of Unit IV can be correlated between all three sites (Fig. 3).

\section{SEDIMENT COMPOSITION AND SOURCE}

The location, size, and thickness of the Bengal Fan point clearly to the principal source of sediment being the rapid denudation of the Himalayan orogenic belt. Detailed petrographic and mineralogic studies have indeed confirmed this inference and provide evidence for temporal variation in the denudation history of the Himalayas as well as for a more varied input to the distal fan (Fig. 14).

The dominant, light-gray silt and mud turbidites (Facies 1 and 2) are the main and constant signature of Himalayan erosion. The coarse-fraction major mineralogy (quartz-feldspar-micas) as well as the clay mineral assemblage (illitechlorite-kaolinite) and stable isotope compositions for $\mathrm{H}, \mathrm{0}$, $\mathrm{Sr}$, and $\mathrm{Nd}$, all indicate a provenance that includes the metamorphic and igneous crystalline rocks of the High Himalayas and the lower grade metamorphics and sedimentary series of the Low Himalayas. These facies are compositionally very similar to those of the Ganges-Brahmaputra river system, the soils of the Indo-Gangetic plain, and recent marine sediments from the proximal and medial Bay of Bengal and from the Indus Fan (Bouquillon et al., Brass and Raman, Yokoyama et al., all this volume).

Comparison of the silt mineralogy (both heavy and light fractions) from the light-gray turbidites, with petrological studies of the Himalayas (Gansser, 1964; Ishida and Ohta, 1973; Sinha Roy, 1977) and of the sub-Himalayan Siwalik Group (Gill, 1951; Sinha, 1970; Chaudhri, 1972), allows us to infer an evolving source region as the Himalayas were uplifted and progressively denuded (Bouquillon et al., this volume). The oldest sediments (17-15 Ma), dominated by quartz and dolomite with scarce Ca-plagioclase and hornblende, were derived from the Precambrian and Paleozoic sedimentary and low-grade metamorphic rocks of the Lower Himalayas. The main metamorphic terrain of the High Himalayas was first unroofed at about $15 \mathrm{Ma}$, with more widespread unroofing from about $11 \mathrm{Ma}$, as shown by the more abundant Caplagioclase, Ca-amphibole, pumpellyite, epidote, and associated heavy mineral suite. The appearance of enstatite, chrome spinel, and serpentinite, followed by olivine in the most recent sediments, attests to the unroofing of a large peridotite body in the High Himalayas between 3.5 and $0.5 \mathrm{Ma}$.

Dating of single crystals of detrital muscovite and $\mathrm{K}$ feldspar by the ${ }^{40} \mathrm{Ar} /{ }^{39} \mathrm{Ar}$ technique gives a broad range of ages for each mineral, but with minimum ages that are approximately the same as the depositional age as determined biostratigraphically. The results indicate that a large proportion of material in the Bengal Fan is first-cycle detritus that can be ascribed to a significant pulse of uplift and rapid erosion in the Himalayas. Available data in the drainage basin suggest that the source of the youngest material (i.e. $<8 \mathrm{Ma}$ ) is the rocks of both the High and Low Himalayas north of the Main Boundary Thrust (Copeland et al., this volume). Detrital apatites dated by fission-track methods give ages that are only $0-10$ m.y. older than the depositional ages (Corrigan and Crowley, this volume). This provides further evidence of very high rates of denudation from source areas similar to the present-day Himalayas, and rapid transportation to the distal Bengal Fan.

The dark-gray, organic-rich, mud turbidites (Facies 3) have a different and distinctive composition and were most probably derived from the western margin of the Bay of Bengal and ultimately from the southern parts of India and Sri Lanka. The smectite-kaolinite clay assemblage, and the D and O stable isotope ratios that indicate soil profile clays, are very similar to those found in the Ceylon Basin as well as along the southeastern coast of India. The relatively high gibbsite content together with the kaolinite is similar to Tertiary laterite formations in southern India (Bouquillon et al., this volume). The $\mathrm{Mg}$-rich ilmenite and An-rich plagioclase are compositionally similar to those of the Deccan Trap basalts, which would also provide a likely source for the smectite clays. The pyrope garnet, brown hornblende, and other distinctive heavy mineral species suggest derivation from the greenschist to granulite facies metamorphic terrains that flank the Deccan Traps in south India and Sri Lanka (Crawford, 1974; Rao, 1974; Yokoyama et al., this volume). The thermal demagnetization curves for these dark-gray turbidites are also similar to those of Deccan Trap basalts (Sager and Hall, this volume).

The dark-gray turbidites also contain small but significant percentages of resedimented nannofossils and terrestrial organic matter. The occurrence of the former and the preservation of the latter both imply that the sediment accumulated first in a shelf or outer slope setting in an area of low-oxygen bottom waters. The western margin of the Bay of Bengal would fit well with this scenario.

The biogenic turbidites (Facies 4) have another, altogether different source. The more common greenish colored ones contain small-sized, well-preserved benthic and planktonic foraminifers, pyritized radiolarians, mollusc, echinoid and ostracod fragments, plant debris, and minor terrigenous material, in the coarser grained fraction. The benthic foraminifer assemblage was derived from an outer shelf-upper slope water depth (Iaccarino and Proto-Decima, this volume). The finer grained fraction comprises nannofossils and a smectitekaolinite-illite clay assemblage, with minor but significant palygorskite (Bouquillon et al., this volume). The most likely source for these sediments appears to be a low-latitude, open shelf-slope setting in an area of good primary productivity and little terrigenous supply such as the shelf off Sri Lanka with additional input of some eolian clays and silts. The palygorskite of the northern Indian Ocean and of the Sri Lankan Basin is believed to have been derived ultimately from the saline 


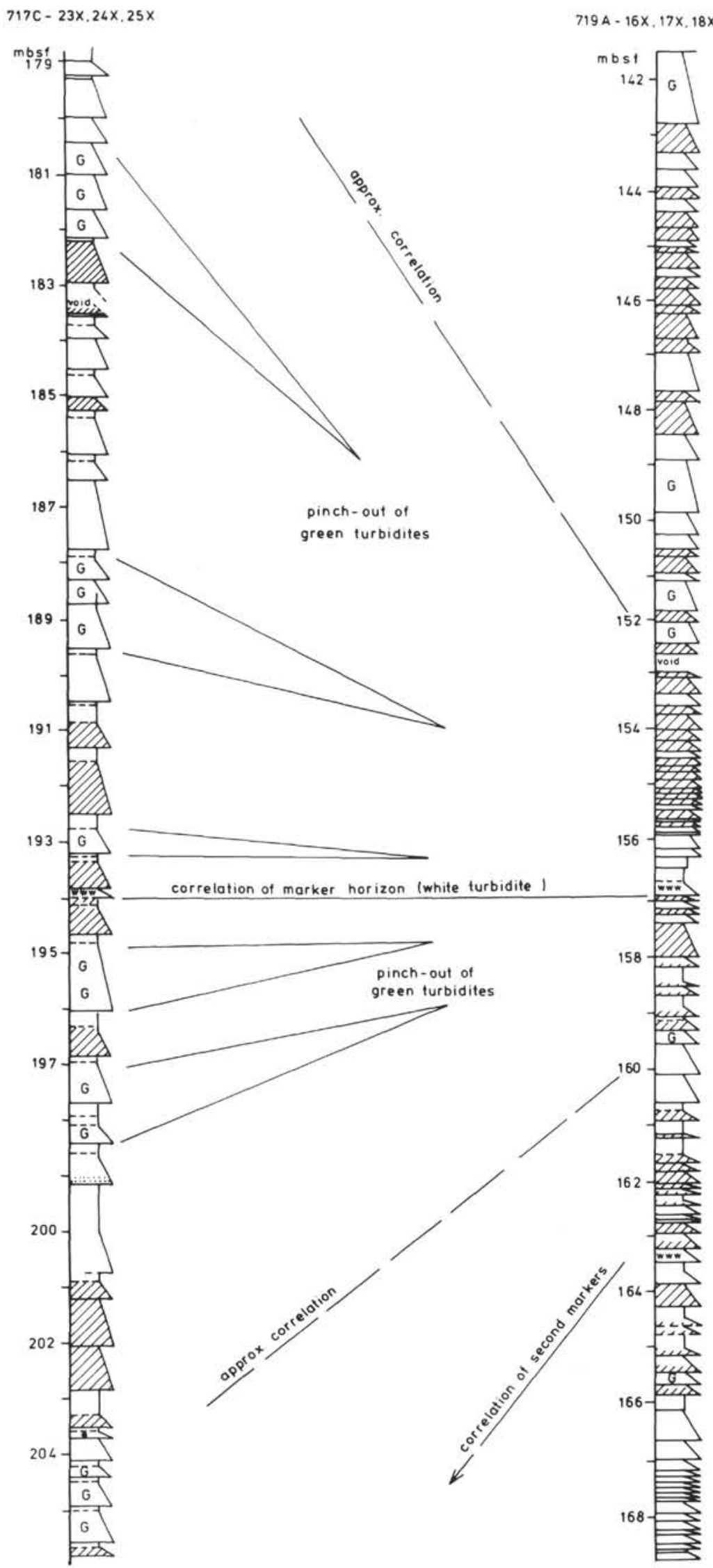

Figure 13. Bed-to-bed correlation of individual turbidites and turbidite packets between Sites 717 and 719 . Facies 1 and 2 (blank ornament, graded beds), Facies 3 (oblique hachure, graded beds), Facies 4 (graded beds; $\mathrm{G}=$ greenish, $\mathrm{W}=$ whitish), Facies 5, 6, and 7 (blank ornament at tops of graded beds). 


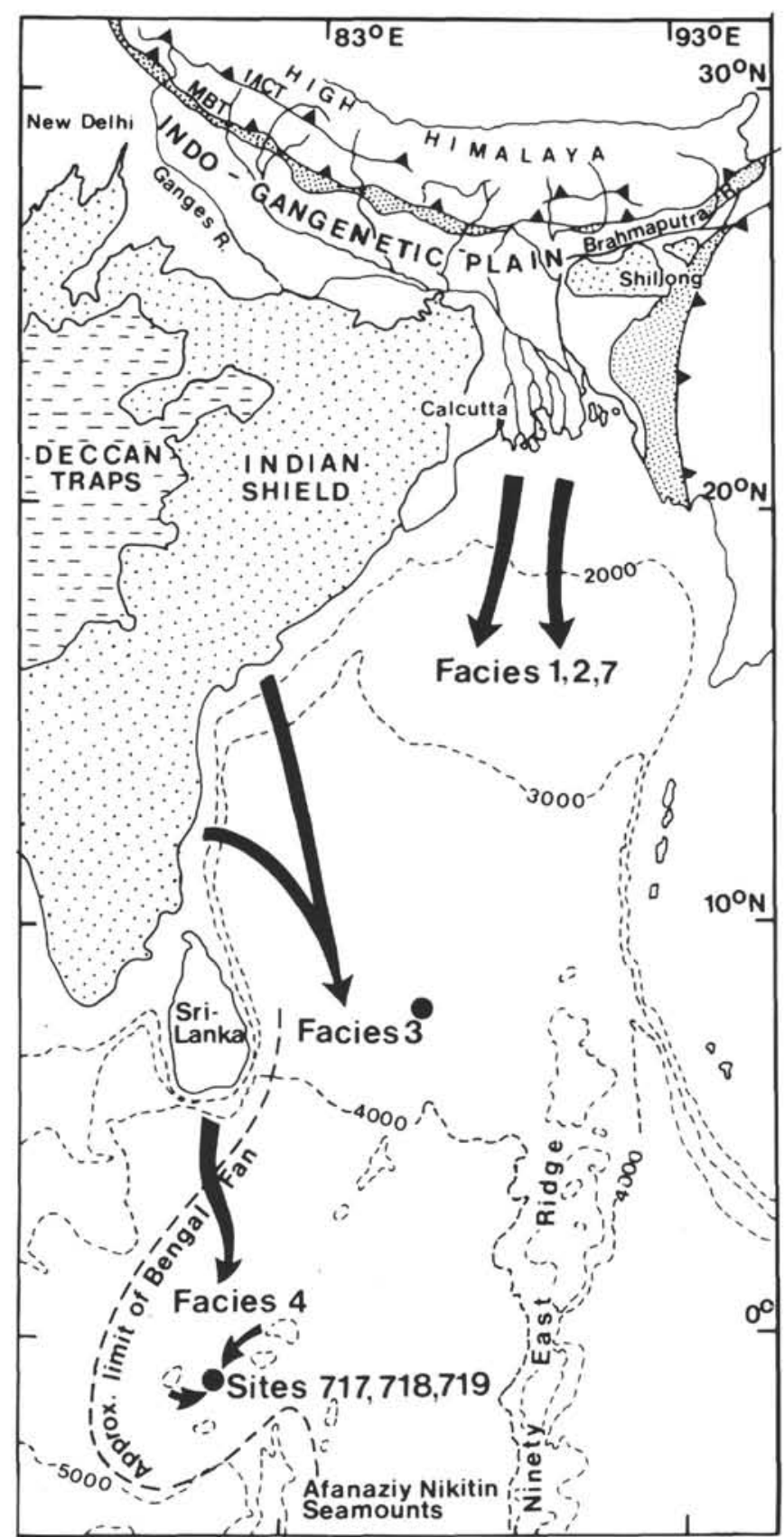

Figure 14. Map of northeast Indian Ocean and surrounding land areas (after Bouquillon et al., this volume) showing main sources of sediment for the Bengal Fan with major supply routes.

deserts of Somalia and Arabia (Kolla et al., 1976; Bouquillon and Debrabant, 1987; Chamley et al., 1989).

The whitish colored biogenic turbidites are less abundant, contain less terrigenous material, and have received little detailed study. The biogenic fraction is dominated by both planktonic and benthic foraminifers, many of which show evidence of extreme dissolution. The assemblages suggest a deeper water, slope-lower bathyal origin, most likely on a local seamount far from the influence of terrigenous input. The dissolution may, in part, have resulted from resedimentation to below the carbonate compensation depth (CCD) and also from early diagenesis.

The pelagic clays and pelagic calcareous clays (Facies 5 and 6) are some of the finest grained sediments encountered and comprise little other than clays, very fine silts, and biogenic material (Facies 6 only). The clay fraction is a mixed assemblage, but without chlorite-presumably because of its relatively coarser grain size derived from the same sources as the turbidites, but with the addition of a minor wind-blown component. The nannofossil-foraminifer assemblages are believed to have suffered the effects of selective dissolution and so are relatively restricted in diversity (Iaccarino and ProtoDecima, this volume). Planktonic foraminifers have apparently undergone the most dissolution; the benthic assemblage suggests the influence of cold abyssal water masses. Apart from the very topmost core section, siliceous microfossils are very rare-this is most probably due to dissolution during early diagenesis (Takahashi, this volume).

The fine-grained nature also applies to the hemiturbidites (Facies 7) and the light-gray parts of these beds have a composition, and presumed source, very similar to the pelagic clays (without the biogenic component). Where the hemiturbidites are darker gray in color or have a dark-gray basal unit, then the composition and source is more closely analogous to the darkgray turbidites (Facies 3). This apparent mixing of source areas is due to the transitional nature of hemiturbidites between hemipelagic and turbiditic (Stow and Wetzel, this volume).

\section{PROCESSES AND CONTROLS ON A DISTAL FAN}

\section{Turbidity Current Processes}

Turbidity currents clearly have been the dominant process operating on the distal Bengal Fan since the early Miocene. Three main types and corresponding sources of turbidity currents can be inferred, as represented by the different facies. The most common, giving rise to the light-gray turbidites (Facies 1 and 2) present throughout the sections at all three sites, shows a distinctive Himalayan source. Erosion, fluvial transport to the Ganges delta/shelf, and resedimentation down-fan over a distance in excess of $2500 \mathrm{~km}$ all took place relatively rapidly.

The average frequency of these events reaching the area of Sites 717-719 on the distal fan is approximately 1 per $1000 \mathrm{yr}$, although we assume that the fan-wide frequency would have been much greater. In some cases the turbidity currents deposited in excess of $1.0 \mathrm{~m}$ of silt and sandy silt (maximum grain size up to coarse sand) at the base of a still thicker graded bed. In other cases, a similar thickness of very fine-grained, graded to structureless mud was deposited, and in still other cases thin-bedded silt-laminated and mud turbidites resulted. These features attest to both the existence of very large and powerful flows that were able to travel hundreds of kilometers over extremely low gradients, as well as to the great variability of flows that reached the distal part of the fan. We infer that the origin of such currents was the major slumping of rapidly deposited, unstable sediments in the delta slope region of the upper fan. Such slumps most likely led to the development of the Swatch-of-no-Ground delta front trough that currently feeds the main active fan channel, as has been shown for the formation of the Mississippi delta front trough (Coleman et al., 1983).

Turbidity currents were also derived from slumping of the outer shelf and upper slope of the southeast Indian continental margin and then moved downslope via channels that acted as tributaries to the main fan channel feeding the distal fan. These currents were less frequent, about one per $10 \mathrm{k} . \mathrm{y}$. , and deposited the dark-gray, organic-rich turbidites (Facies 3). They appear to have been more common during the deposition of Units III and IV of late Miocene and Pliocene age than at other times, although this might simply be an effect of masking by Himalayan-derived material at other times. 
Of still less frequent occurrence were the turbidity currents that brought biogenic debris to the distal fan. Those that deposited the greenish colored turbidites (Facies 4) occurred approximately once every $100 \mathrm{k} . \mathrm{y}$. and are believed to have originated from slumping on the steep slope off Sri Lanka.

The characteristics of the turbidites deposited by these different flows are very similar to many others described from deep marine settings (e.g., Piper, 1978; Kelts and Arthur, 1982; Stow and Piper, 1984; Stow et al., 1986). They are typically of the $\mathrm{T}_{5-8}, \mathrm{~T}_{6-8}$, or $\mathrm{T}_{7-8}$ type (Stow and Shanmugam, 1980), or the E2-E3 turbidites of Piper (1978), but may also show some of the lower divisions of silt-laminated mud. They appear to have been deposited from single large turbidity currents, with no evidence of ponding or reflections causing multiple repetition of turbidite divisions.

\section{Pelagic Processes}

With such rapid and continuous turbidite sedimentation even on this distal part of the fan, there is relatively little in the way of pelagic sediment preserved. Thin pelagic beds do occur, however, at the tops of many of the mud and biogenic turbidites within Units I, III, and IV, and also above the thin-bedded greenish colored silt-mud turbidites that are characteristic of Unit Vb at Site 718. Pelagic clayey oozes (Facies 6 ) are only present within the top meter of the section. Calcareous pelagic clays (also Facies 6) with residual, solution-resistant microfossils occur in sediments back to about 2 Ma (middle part of Unit III), and then give way down-section to pale gray to whitish gray-colored pelagic clays with an absence of fossils (Facies 5). Greenish and reddish brown, unfossiliferous pelagic clays become more common from about $10 \mathrm{Ma}$ to the base of the recovered section.

The rapid and progressive down-section decrease in the carbonate content of the pelagites indicates that the CCD was well above the sediment surface in the early Miocene central Indian Ocean. The CCD became deeper with time through the Miocene and Pliocene. From about 2-3 Ma to the present the seafloor appears to have been somewhere between the CCD and the lysocline.

\section{Hemiturbidite Deposition}

The sediments described in this paper as Facies 7 and called hemiturbidites by Stow and Wetzel (this volume), occur in association with, but are distinctive from, the normal turbidites and pelagites. In many respects they appear to be transitional between these two types and, we suggest, are most probably deposited by a process transitional between a true turbidity current and slow pelagic settling.

It is clear that a turbidity current, having traveled over 2500 $\mathrm{km}$ and deposited thick mud turbidites on an extremely low gradient, will eventually die out. Indeed, many flows probably die out before reaching the distal fan. In its final stages, a muddy turbidity current most probably becomes extremely dilute and begins to mix upward or to peel off into the water column, hence leaving its very finest material as a dilute suspension cloud that extends perhaps up to more than $1 \mathrm{~km}$ above the ocean floor. Further material is added to this cloud as the tail of the turbidity current arrives in the area over a period of, perhaps, a few days to a week or more. Material from this suspension then settles slowly to the seafloor together with any pelagic material in the water column, and is deposited over the distal feather edge of the muddy turbidite from the original current, as well as beyond the point that the "true turbidite" has reached.

Sedimentation from this suspension cloud is sufficiently slow that bioturbation continues throughout. Very approximate estimates, made on the basis of rates of bioturbation in the deep sea and the nature of the burrowing, suggest that deposition of a 1-m thick hemiturbidite took in the order of 2-12 months (Stow and Wetzel, this volume). Although admixed with a certain amount of pelagic rain, the composition of the bed remains essentially turbiditic and very slight normal grading can be observed, especially where the bed overlies a thin turbidite unit.

The process of hemiturbidite deposition proposed here (Fig. 15), or something very similar, has been inferred previously (e.g., Stanley, 1983), and it would appear to be the logical extension of deposition from a turbidity current at its extreme distal end. Some degree of ponding or marked change in gradient might in fact enhance the development of a suspension cloud, and it might be that the slight positive relief afforded by the protruding noses of east-west trending fault blocks in the area has affected southward-flowing turbidity currents in this way. It is also possible that this extreme flow dilution and slow sedimentation may be more common for unconfined than for channelized turbidity currents.

\section{Tectonic vs. Sea-level Controls}

The two major controls on sedimentation on the distal Bengal Fan, at least from the early Miocene to Holocene, were Himalayan uplift (tectonics) and eustatic changes in sea level (Cochran, Stow, et al., 1989). However, it has proved impossible in this study to disentangle the effects of one from those of the other (Fig. 16).

In a general way, the dominance of silty turbidites with Himalayan signature through much of the Miocene and in the late Pleistocene is probably related to two distinct phases of Himalayan uplift (Gansser 1964, 1981) corresponding to beginning of motion on the main central thrust (MCT) at 18-20 $\mathrm{Ma}$, and to the most recent phase of activity on the main boundary thrust (MBT) at about 1 Ma. Rapid sedimentation rates during these periods (Units V and II) and single-crystal dating results that indicate a short time period from uplift through erosion and transportation to deposition, both argue for strong tectonic influence on sedimentation. The very rapid sedimentation rate during most of the last $0.8 \mathrm{Ma}$, as seen at Site 717 in particular, can be correlated to the deposition of very thick molasse in the central Himalayas during the Pleistocene (Searle et al., 1987; Le Fort, 1989). However, the exact nature and timing of Himalayan uplift is still a matter of some controversy (see discussion in Cochran, this volume).

The composition of the silt fraction in the turbidites is seen to change systematically from the base to top of the sections examined (Yokoyama et al., this volume). That this can be closely related to uplift history in the Himalayas again emphasizes the importance of Himalayan events even some 4000 to $5000 \mathrm{~km}$ down the transport pathway.

On many deep-sea fans and other turbidite systems studied, a close correlation has been observed between eustatic sea-level fluctuation and the supply of coarse detritus via turbidity currents (e.g., Stow et al., 1983; Shanmugam and Moiola, 1986). There is no reason to suppose that the Bengal Fan should be any different, and when the most recent low-frequency curve of eustatic sea-level change is compared with the sedimentary record from the distal fan sites there is good correspondence in some but not all parts (Fig. 16). In particular, the mud-rich Units III and IV correlate with a period of generally higher sea level, at least initially. Higher relative sea levels would tend to trap the coarser grained material on the shelf areas and slow the overall rate of resedimentation to the deep fan. This in turn would have allowed for the greater influence of slumping and resedimentation from the southeast Indian and Sri Lankan margins, so that turbidites from these sources are interbedded with mud 


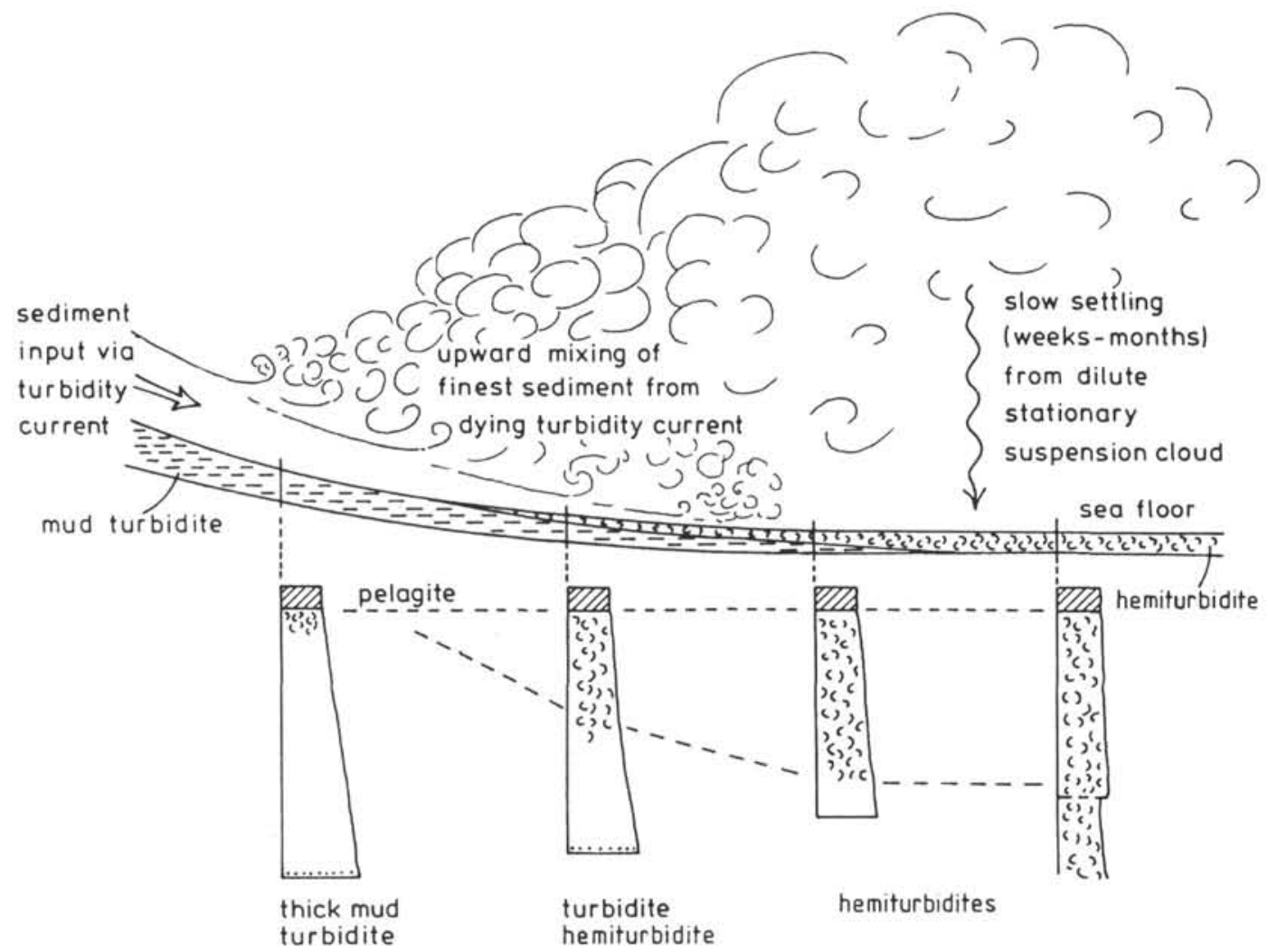

Figure 15. Schematic diagram of the hemiturbidite depositional process (see text for discussion).
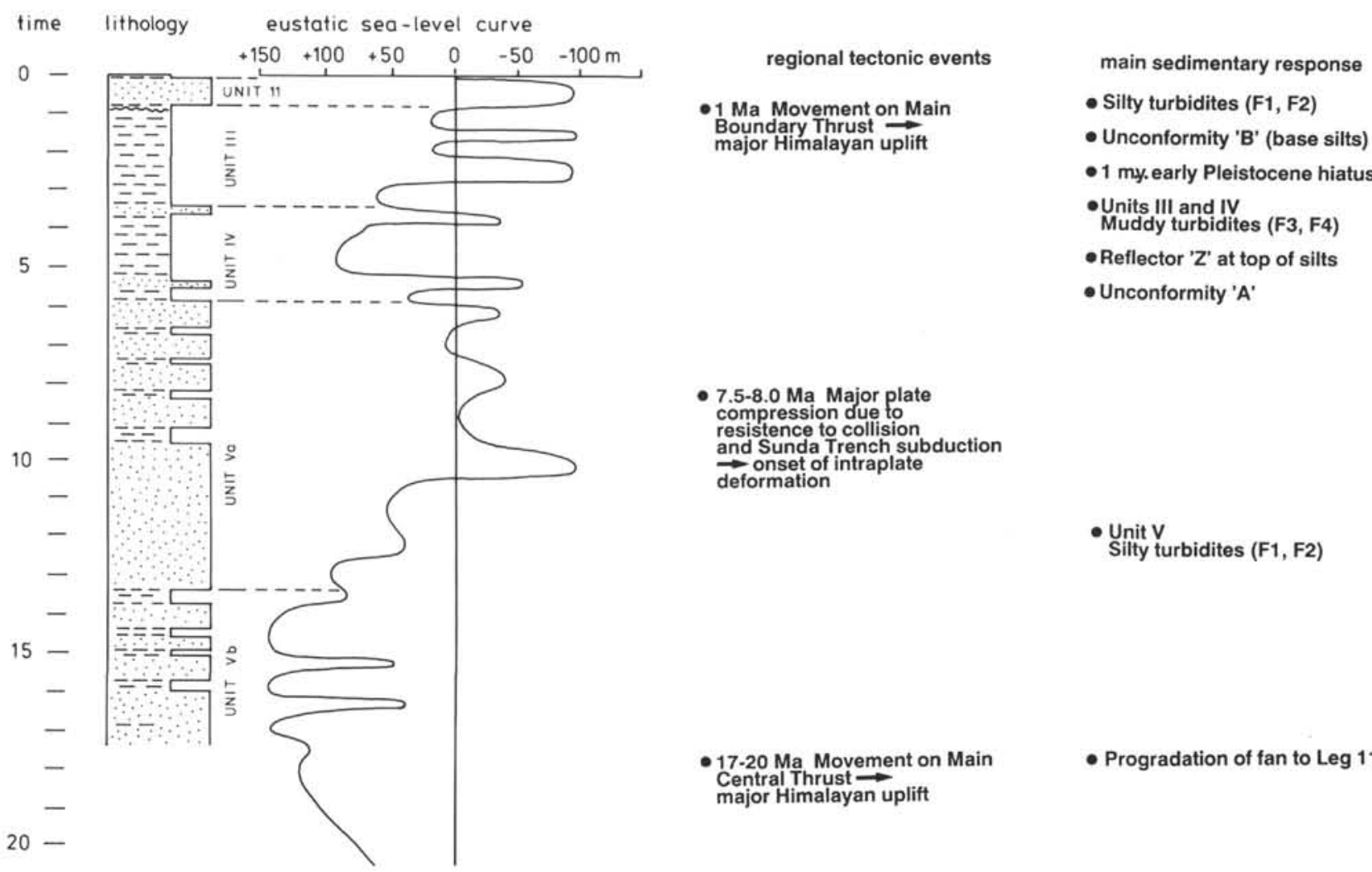

- 7.5-8.0 Ma Major plate compression due to resistence to collision and Sunda Trench subduction $\rightarrow$ onset of intraplate deformation

- Unit V

Silty turbidites (F1, F2)

-17-20 Ma Movement on Main major Himalayan uplift

- Progradation of fan to Leg 116 area

Figure 16. Summary lithostratigraphic section compiled from all three Leg 116 sites, compared with the eustatic sea-level curve (Haq et al., 1987), principal regional tectonic events, and sedimentary response on the distal Bengal Fan. Y-axis: time in Ma. 
turbidites from the Ganges delta/shelf, as shown by compositional studies of both coarse and fine fractions (Brass and Raman, Bouquillon et al., Yokoyama et al., all this volume).

The onset of rapid, silt-rich turbidite sedimentation again in the late Pleistocene (Unit II) would certainly have been enhanced by lowered sea level at that time, even if Himalayan uplift were an equally or more important control. However, the mid-Miocene high stand and the many sea-level oscillations through the Pliocene-Pleistocene are not all directly reflected in the sedimentary record. This may be partly because low core recovery in the silty units decreases resolution but may also imply the overprint of a tectonic or other control.

\section{Internal Fan Growth Controls}

With a system the size and complexity of the Bengal Fan, there are many other factors that have to be taken into account when assessing the controls on sedimentation. Normal processes of fan growth, including channel avulsion and lobe switching, can markedly affect the pattern of sedimentation in one small area such as the part of the distal fan covered by this study. For example, the intervals of mud-rich deposition within the silty units and of silt-rich turbidites within the muddy units could be related to channel and lobe migration. It is also possible that a greater change in the supply direction of the main active channel or channels, for example directing sediment to the Nicobar rather than to the Bengal Fan, could have very significantly affected sedimentation in the study area. This process could equally well explain the deposition of the mud-rich Units III and IV, or account for the 1-m.y. Pleistocene hiatus encountered at all three sections (Gartner, this volume).

There have also been local effects related to intraplate deformation and motion on the faults. The marked reduction in the thickness of the upper units at Sites 718 and 719 relative to 717 (Fig. 3), is related to their higher position on the fault blocks. The thinning and pinching out of individual turbidites and the consequent microcycles of variation in turbidite thickness observed, can be explained by the existence of slight seafloor relief (say $10-50 \mathrm{~m}$ ) along the protruding edges of fault blocks. The east-west trend of this relief presented an obstacle for the southward-flowing turbidity currents, which were either deflected or thinned and so deposited fewer and thinner turbidites higher up the blocks.

\section{REFERENCES}

Bouquillon, A., and Debrabant, P., 1987. Distribution des mineraux argileux dans l'Ocean Indien Nord Oriental. J. Rech. Oceanogr., $12: 8-11$.

Chamley, H., Debrabant, P., and Bouquillon, A., 1989. Environmental significance of detrital palygorskite in late Cenozoic sediments of the northwestern Indian Ocean. AIPEA, 9: Strasbourg. (Abstract)

Chaudrhi, R. S., 1972. Heavy minerals from the Siwalik formations of the northwestern Himalayas: Sediment. Geol., 8:77-82.

Cochran, J. R., Stow, D.A.V., et al., 1989. Proc. ODP, Init. Repts., 116: College Station, TX (Ocean Drilling Program).

Coleman, J. M., Prior. D. B., and Lindsay, J. F., 1983. Deltaic influences on shelf-edge instability processes. In Stanley, D. J., and Moore, G. T. (Eds.), The Shelf Break: Critical Interface on Continental Margins. SEPM Spec. Publ. 33:121-137.

Crawford, A. R., 1974. Indo-Antarctica, Gondwanaland, and the distortion of a granulite belt. Tectonophysics, 22:141-157.

Curray, J. R., Moore, D. G., 1971. Growth of the Bengal deep-sea fan and denudation of the Himalayas. Geol. Soc. Am. Bull., 82:563-572.

Curray, J. R., Emmel, F. J., Moore, D. G., Raitt, R. W., 1982. Structure, tectonics and geological history of the northeastern Indian Ocean. In Nairn, A.E.M., Stehli, F. G. (Eds.). The Ocean Basins and Margins (Vol. 6). The Indian Ocean: New York (Plenum Press), 399-450.

Emmel, F. J., and Curray, J. R., 1984. The Bengal submarine fan, north-eastern Indian Ocean. Geo-Mar. Lett., 3:119-124.
Gansser, A., 1964. The Geology of the Himalayas: New York (Wiley Interscience).

1981. The geodynamic evolution of the Himalaya. In Gupta, H. K., and Delany, F. M. (Eds.), Zagros, Hundu Kush, Himalaya Geodynamic Evolution. Geodynamic Series 4: Washington (Am. Geophys. Union, 111-121.

Geller, C. A., Weissel, J. K., Anderson, R. N., 1983. Heat transfer intraplate deformation in the central Indian Ocean. J. Geophys. Res., 88:1018-1032.

Gill, W. D., 1951. The stratigraphy of the Siwalik Series in the northern Potwar, Punjab, Pakistan: Q.J. Geol. Soc. London, 107:375-394.

Haq, B. U., Hardenbol, J., and Vail, P. R., 1987. Chronology of fluctuating sea levels since the Triassic. Science, 235:1156-1167.

Ishida, R. and Ohta, Y., 1973. Ramechhap-Okhaldhunga region. In Hashimota, S., Himalayan Committee of Hokkaido Univ. (Supervisor), Geology of the Nepal Himalayas. Sapporo (Hokkaido Univ.), 35-67.

Kelts, K., and Arthur, M. A., 1981. Turbidites after ten years of deep-sea drilling-wringing out the mop? SEPM Spec. Publ., 32:91-127.

Kolla, V., Moore, D. G., Curray, J. R., 1976. Recent bottom current activity in the deep western Bay of Bengal. Mar. Geol., 21: 255-270.

Le Fort, P., 1989. The Himalayan orogenic segment. In Sengor, A.M.C. (Ed.), Tectonic evolution of the Tethyan region. Proc. NATO ASI meeting, Istanbul, Turkey, October 1985. New York (D. Reidel Publ. Co.).

Piper, D.J.W., 1978. Turbidite muds and silts on deep-sea fans and abyssal plains. In Stanley, D. J., and Kelling, G. (Eds.), Sedimentation in Submarine Canyons, Fans and Trenches. Stroudsberg, PA. (Dowden, Hutchinson \& Ross), 163-176.

Ricci Lucchi, F., 1975. Depositional cycles in two turbidite formations of the northern Apennines, Italy. J. Sediment. Pet., 45:3-43.

Searle, M. P., Windley, B. F., Coward, M. P., Cooper, D.J.W.., Rex, A. J., Rex, D., Li Tingdong, Xiao Xuchang, Jan, M. Q., Thakur, V. C., and Kumar, S., 1987. The closing of Tethys and the tectonics of the Himalaya. Geol. Soc. Am. Bull., 98:678-701.

Shanmugham, A., and Moiola, R.J., 1988. Submarine fans: characteristics, models, classification, and reservoir potential. Earth-Sci. Rev., 24:383-428.

Sinha, R. N., 1970. Heavy mineral investigations in the Siwaliks of Mohand, District Saharanpur, Uttar Pradesh, India: J. Geol. Soc. India, 11:163-177.

Sinha Roy, S., 1977. Metamorphism and tectonics of the Himalayas, as illustrated in the Eastern Himalayas: Geotectonics, 11:120-124.

Stanley, D. J., 1983. Parallel-laminated deep-sea muds and coupled gravity-flow hemipelagic settling in the Mediterranean. Smithson. Contrib. Mar. Sci., 19.

Stow, D.A.V., 1985. Deep-sea clastics: where are we and where are we going? In Brenchley, P. J., Williams, B.P.J. (Eds.), Sedimentology: Recent Developments and Applied Aspects. Geol. Soc. London Spec. Publ., 18: Oxford (Blackwell Scientific Publications), 67-94.

Stow, D.A.V. and Shanmugam, G., 1980. Sequences of structures in fine-grained turbidites: comparison of recent deep-sea and ancient flysch sediments. Sediment. Geol., 25:23-42.

Stow, D.A.V., and Piper, D.J.W., 1984. Deep-water fine-grained sediments: facies models. Geol. Soc. London Spec. Publ., 15: Oxford (Blackwell Scientific Publications), 611-645.

Stow, D.A.V., Howell, D. G., Nelson, C. H., 1983. Sediment, tectonic and sea level controls on submarine fan and slope-apron turbidite systems. Geo-Mar. Lett., 3:57-64.

Stow, D.A.V., Cremer, M., Droz, L., Meyer, A. W., Normark, W. R., O'Connell, S., Pickering, K. T., Stelting, C. E., Angell, S. A., and Chaplin, C., 1986. Facies, composition, and texture of Mississippi Fan sediments, Deep Sea Drilling Project Leg 96, Gulf of Mexico. In Bouma, A. H., Coleman, J. H., Meyer, A. W., et al., Init. Repts. DSDP, 96: Washington (U.S. Govt. Printing Office), 475-487.

Thompson, R. W., 1974. Mineralogy of sands from the Bengal and Nicobar fans, Sites 218 and 211, eastern Indian Ocean. In von der Borsch, C. C., Sclater, J. C., et al., Init. Repts. DSDP, 22: Washington (U.S. Govt. Printing Office), 711-713. 
Venkatathnam, K., and Biscaye, P. E., 1973. Clay mineralogy and sedimentation in the eastern Indian Ocean. Deep-Sea Res., 20:727-738.

von der Borsch, C. C., Sclater, J. G., et al., 1974. Site 218. In von der Borsch, C. C., Sclater, J. G., et al., Init. Repts. DSDP, 22: Washington (U.S. Govt. Printing Office), 325-348.
Weissel, J. K., Anderson, R. N., Geller, C. A., 1980. Deformation of the Indo-Australian Plate. Nature, 287:284-291.

Date of initial receipt: 9 February 1990

Date of acceptance: 16 February 1990

Ms 116B-110 